\title{
Whole-Cell Chloride Currents in Rat Astrocytes Accompany Changes in Cell Morphology
}

\author{
Christopher D. Lascola ${ }^{1}$ and Richard P. Kraig ${ }^{1,2}$ \\ ${ }^{1}$ Committee on Neurobiology and 2 Departments of Neurology and Pharmacological and Physiological Sciences, The \\ University of Chicago, Chicago, Illinois 60637
}

\begin{abstract}
Astrocytes can change shape dramatically in response to increased physiological and pathological demands, yet the functional consequences of morphological change are unknown. We report the expression of $\mathrm{Cl}^{-}$currents after manipulations that alter astrocyte morphology. Whole-cell $\mathrm{Cl}^{-}$ currents were elicited after (1) rounding up cells by brief exposure to trypsin; (2) converting cells from a flat polygonal to a process-bearing (stellate) morphology by exposure to serum-free Ringer's solution; and (3) swelling cells by exposure to hypo-osmotic solution. Zero-current potentials approximated the Nernst for $\mathrm{Cl}^{-}$, and rectification usually followed that predicted by the constant-field equation. We observed heterogeneity in the activation and inactivation kinetics, as well as in the relative degree of outward versus inward rectification. $\mathrm{Cl}^{-}$conductances were inhibited by 4,4-diisothiocyanostilbene-2,2'-disulfonic acid $(200 \mu \mathrm{M})$ and by $\mathrm{Zn}^{2+}(1 \mathrm{~mm})$. Whole-cell $\mathrm{Cl}^{-}$currents were not expressed in cells without structural change.
\end{abstract}

We investigated whether changes in cytoskeletal actin accompanying changes in astrocytic morphology play a role in the induction of shape-dependent $\mathrm{Cl}^{-}$currents. Cytochalasins, which disrupt actin polymers by enhancing actin-ATP hydrolysis, elicited whole-cell $\mathrm{Cl}^{-}$conductances in flat, polygonal astrocytes. In stellate cells, elevated intracellular $\mathrm{Ca}^{2+}(2 \mu \mathrm{M})$, which can depolymerize actin, enhanced $\mathrm{Cl}^{-}$currents, and high intracellular ATP $(5 \mathrm{~mm})$, required for repolymerization, reduced $\mathrm{Cl}^{-}$currents. Modulation of $\mathrm{Cl}^{-}$current by $\mathrm{Ca}^{2+}$ and ATP was blocked by concurrent whole-cell dialysis with phalloidin and DNase, respectively. Phalloidin stabilizes actin polymers and DNase inhibits actin polymerization. Dialysis with phalloidin also prevented hypo-osmotically activated $\mathrm{Cl}^{-}$currents. These results demonstrate how the expression of astrocyte $\mathrm{Cl}^{-}$currents can be dependent on cell morphology, the structure of actin, $\mathrm{Ca}^{2+}$ homeostasis, and metabolism.

Key words: astrocyte; chloride current; morphology; actin; calcium; ATP
Changes in astrocyte morphology are a hallmark of virtually all pathological events in brain (Ransom and Kettenmann, 1995). These morphological changes can include hypertrophy (Petito et al., 1990), process elaboration and reorientation (Mathewson and Berry, 1985), and/or swelling (Kimelberg et al., 1989). Changes in astrocyte shape are also seen with less injurious perturbations (Kraig et al., 1991) and even accompany physiological processes such as motor learning (Anderson et al., 1994.) The relationship between cell slape and astrocyte function, however, remains poorly understood.

One astrocyte function that may change with alterations in cell shape is ion homeostasis. Changes in the expression of several astrocyte ion conductances follow exposure to dibutyryl cAMP (Barres et al., 1989) and phorbol esters (Backus et al., 1991), and also occur during coculture with neurons (Corvalan et al., 1990), all conditions that transform cultured astrocytes from a flat,

Received Nov. 21, 1995; revised Jan. 5, 1996; accepted Jan. 10, 1996.

This work was supported by grants from the National Institute of Neurological Disorders and Stroke (NS-19108), the American Heart Association of Metropolitan Chicago, and the Brain Research Foundation of The University of Chicago. C.D.L. was supported by an MD/PhD Training Grant in Growth and Development (HD07009) from the National Institute of Child Health and Human Development, and a National Research Service Award (F31-MH11126) from the National Institute of Mental Health. We thank Dr. Deborah Nelson, Dr. Philip Kunkler, and Anthony Caggiano for helpful discussions and for reading this manuscript, Marcia Kraig for assistance with tissue culture preparation, and Raymond Hulse for image enhancement and restoration.

Correspondence should be addressed to Richard P. Kraig, Department of Neurology, MC 2030, University of Chicago, 5841 South Maryland Avenue, Chicago, IL 60637.

Copyright $\odot 1996$ Society for Neuroscience $0270-6474 / 96 / 162532-14 \$ 05.00 / 0$ polygonal to a process-bearing (stellate) morphology (Levison and McCarthy, 1991). In addition, osmotic swelling in cultured astrocytes seems to induce a $\mathrm{Cl}^{-}$permeability requisite for regulatory volume decrease (RVD) (Pasantes-Morales et al., 1994).

Astrocytic ion homeostasis inevitably involves the movement of $\mathrm{Cl}^{-} \cdot \mathrm{Cl}^{-}$serves as an important counter anion to $\mathrm{K}^{+}$uptake and is a transported species on ion exchangers and cotransporters carrying $\mathrm{H}^{+}$equivalents (Kimelberg et al., 1986). Although increases in intracellular $\mathrm{Cl}^{-}$concentration $\left(\left[\mathrm{Cl}^{-}\right]_{\mathrm{i}}\right)$ accompanying astroglial depolarization (Ballanyi et al., 1987; Walz and Mukerji, 1988) suggest the presence of electrogenic $\mathrm{Cl}^{-}$transport, reports of single anion channels in resting astrocytes indicate that $\mathrm{Cl}^{-}$ channels are normally not functional. Channel activity requires excision of the membrane patch (Barres et al., 1990b) and, in the case of large-conductance anion channels, on the proximity of the membrane potential to $0 \mathrm{mV}$ (Sonnhof, 1987) and/or the zerocurrent potential (Jalonen, 1993). In one series of reports, however, Bevan et al. (1985) and Gray and Ritchie (1986) observed voltage-dependent whole-cell $\mathrm{Cl}^{-}$currents activated at potentials more positive than $-50 \mathrm{mV}$.

We used the whole-cell patch-clamp technique to reexamine $\mathrm{Cl}^{-}$currents in rat type- 1 neocortical cultured astrocytes and to determine whether whole-cell current expression depends on changes in cell morphology. Consistent with most studies (for review, see Barres et al., 1990b), we did not observe any $\mathrm{Cl}^{-}$ conductance in control astrocytes with a flat, polygonal morphology. In contrast, cells expressed whole-cell $\mathrm{Cl}^{-}$currents after being rounded up by brief exposure to trypsin, a technique used by 
Gray and Ritchie (1986) in their experiments to facilitate patchclamp recording. Additional experiments demonstrated that other alterations in astrocytic shape, i.e., transformation from flat to stellate by exposure to serum-free Ringer's solution and osmotic swelling, also elicited $\mathrm{Cl}^{-}$currents.

Changes in astrocytic morphology can involve changes in the actin cytoskeleton (Goldman and Abramson, 1990; Baorto et al., 1992). Moreover, cytoskeletal actin is functionally and structurally associated with several ion channels (Guharay and Sachs, 1984; Srinivasan et al., 1988; Hudspeth, 1989; Cantiello et al., 1991; Froehner, 1991; Johnson and Byerly, 1993; Rosenmund and Westbrook, 1993; Suzuki et al., 1993; Haussler et al., 1994; Schwiebert et al., 1994; Levitan et al., 1995). Accordingly, we investigated whether changes in actin play a role in shape-dependent $\mathrm{Cl}^{-}$ current expression. Modulation of $\mathrm{Cl}^{-}$conductances by cytochalasins, $\mathrm{Ca}^{2+}$, ATP, phalloidin, and DNase, all agents that act on the actin cytoskeleton, demonstrated how changes in the state of actin polymerization may underlie the expression of shapedependent $\mathrm{Cl}^{-}$current expression in cultured astrocytes and how $\mathrm{Cl}^{-}$currents may ultimately be controlled by $\left[\mathrm{Ca}^{2+}\right]_{i}$ and energy supply, two physiological parameters inextricably linked to astrocyte functions within the nervous system.

\section{MATERIALS AND METHODS}

Cell culture preparation. Neocortical type-1 astrocytes were prepared and purified from primary cultures of neonatal rat brain by a modification of the methods of McCarthy and de Vellis (1980). Brains were removed from halothane-anesthetized 0 - to 2 -d-old rat pups and stripped of their meninges. Portions of both frontal and parietal cortices were dissected, and any remaining meninges and blood vessels were carefully removed. The cortical tissue was minced to $1 \mathrm{~mm}$ pieces with a scalpel blade in cold $\left(4-10^{\circ} \mathrm{C}\right) \mathrm{HBSS}$ and was mechanically dissociated further by sequential passage through $18,20,24$, and 26 gauge needles, with final passage through a $53 \mathrm{~mm}$ Nytex screen. The cells were centrifuged at $150 \times \mathrm{g}$ for $7 \mathrm{~min}$; the pellet was resuspended in DMEM with $10 \%$ fetal calf serum, and the cells were plated in $25 \mathrm{~cm}^{2}$ flasks. The medium was changed initially at $24 \mathrm{hr}$ and then once every $4-5 \mathrm{~d}$ thereafter. At 7-10 d, the culture consisted of a top layer of type-2-like astrocytes, glial progenitor cells, and microglia residing on a confluent layer of neocortical type-1 astrocytes (Levison and McCarthy, 1991). After 3-6 weeks, the cells on the confluent layer were removed using a variant of the "shaking off" procedure (McCarthy and de Vellis, 1980). Culture flasks were shaken vigorously at $225 \mathrm{rpm}$ for $20 \mathrm{hr}$; their media were refreshed and then reshaken for another $20 \mathrm{hr}$. The type-1-like cells were trypsinized $(0.025 \%)$ from the flask and replated at lower densities onto alcohol- and flame-sterilized $25 \mathrm{~mm}$ diameter round coverslips. The final cultures consisted of $98 \%$ pure neocortical type- 1 astrocytes, based on immunohistochemical labeling with markers to glial fibrillary acidic protein (GFAP) and A2B5 (type-2-like astrocytes), as well as DiI-Ac-LDL inclusion by microglia. Electrophysiological recordings were made between days 3 and 12 after replating and before cells becane confluent.

Immunohistochemical and cytochemical characterization. Staining of cytoskeletal actin and GFAP was carried out as follows. Astrocytes were rinsed three times in PBS and then fixed with acetone for $15 \mathrm{~min}$ at $-20^{\circ} \mathrm{C}$. After three washes in PBS, cells were incubated for $30 \mathrm{~min}$ in PBS containing $3 \%$ normal goat serum and $0.25 \%$ Triton X-100 (PBS-X). Cells were then incubated for $1 \mathrm{hr}$ in PBS-X containing either primary antibody to GFAP at 1:50 dilution or fluorescein isothiocyanate (FITC)conjugated phalloidin (for actin) at 1:10 dilution of a $26.4 \mathrm{~mm}$ stock solution (methanol as solvent.) After several rinses with PBS-X, cells stained for GFAP were incubated for 30 min with a rhodamineconjugated secondary antibody. After three final washes in PBS, covcrslips were mounted onto slides using aqueous gel-mount and examined for immunofluorescence.

For A2B5, cells were washed three times in PBS and then fixed with 4\% paraformaldehyde for $15 \mathrm{~min}$. PBS containing $3 \%$ normal goat serum and no Triton X-100 (PBS-GS) was used for $30 \mathrm{~min}$ of blocking incubation and as the diluent for the primary and secondary antibodies. A2B5 was used at $10 \mathrm{mg} / \mathrm{ml}$. After several washes with PBS-GS, plates were incu- bated with an appropriate rhodamine-conjugated secondary antibody, washed again in PBS-GS, and mounted on slides with aqueous gel-mount

For DiI-Ac-LDL microglial staining (Giulian and Baker, 1986), cells were washed several times in standard $150 \mathrm{~mm} \mathrm{NaCl}$ Ringer's solution (for Ringer's recipe, see Solutions) and then incubated in Ringer's solution containing Dil-Ac-LDL at a concentration of $10 \mathrm{mg} / \mathrm{ml}$. Plates were examined for immunofluorescence without fixation.

Illustrations were prepared from electronic images in accord with recent discussions (Anderson, 1994). Fluorescent images were photographed using 100 ASA Ektachrome film (Eastman Kodak, Kochester, NY) with an Orthomat E automatic exposure unit (Leica, St. Gallen, Switzerland) and a Laborlux D compound microscope (Leica). Resultant slides were transformed into electronic files using a Kodak Professional Film Scanner (model 2035, Eastman Kodak) at 1000 pixels/inch. Electronic images were processed using Image Pro Plus software (version 1.3 Media Cybernetics, Silver Spring, MD). First, images were refocused using a "hi Gaussian" filter [ $7 \times 7$ pixel matrix at $50 \%$ strength and two passes (see Fig. 1) and 100\% strength and one pass (sce Fig. 10)]. Sccond, image brightness was raised and background noise was lowered by applying brightness, contrast, and $\gamma$ function values of 70,60 , and 0.5 to all pictures. Final images were printed using a dye sublimation printer (XLT-7720; Eastman Kodak).

Solutions. In most experiments, whole-cell currents were obtained using asymmetrical $\mathrm{Cl}^{-}$solutions (Nernst ${ }_{\mathrm{Cl}^{-}}=-31 \mathrm{mV}$ ), allowing us to identify an increase in leak conductance as a depolarizing shift in the zero-current potential. The pipette solution contained (in $\mathrm{mM}$ ): 40 $\mathrm{N}$-methyl-D-glucamine (NMDG)-Cl, $100 \mathrm{NMDG}$-gluconate, $2 \mathrm{MgCl}_{2}$, and 10 HEPES, and a $\mathrm{Ca}^{2+}$-EGTA buffer to yield a desired free $\mathrm{Ca}^{2+}$ concentration buffered to $\mathrm{pH} 7.2$. $\mathrm{Ca}^{2+}$-EGTA buffer solutions were prepared according to the procedure described by Neher (1988), and final free $\mathrm{Ca}^{2+}$ concentrations were calculated assuming an apparent dissociation constant of the $\mathrm{Ca}^{2+}$-EGTA complex of 0.15 mm at pH 7.2. $\mathrm{Ca}^{2+}$ concentrations for individual experiments are indicated in the text and figure legends. The bath solution contained (in mM): $140 \mathrm{NMDG}-\mathrm{Cl}, 2$ $\mathrm{CaCl}_{2}, 2 \mathrm{MgCl}_{2}$, and 10 HEPES butfered to $\mathrm{pH}$ 7.4. Gluconate replaced $\mathrm{Cl}^{-}$in $\mathrm{Cl}^{-}$substitution experiments. The addition of ATP (as $\mathrm{Mg}^{2+}$ salt) and cytoskeletal reagents to either bath or pipette solutions is as indicated in the text and figure legends. Most incubations with or without pharmacological agents used a Ringer's solution as follows (in mM): $140 \mathrm{NaCl}, 3$ $\mathrm{KCl}, 1.5 \mathrm{CaCl}_{2}, 1 \mathrm{MgCl}_{2}, 10$ dextrose, 10 HEPES, pH 7.4. Trypsin incubations were performed in divalent cation-free HBSS. Approximately half of our electrophysiological experiments were also carried out in the presence of $0.1 \mathrm{~mm} \mathrm{LaCl}{ }_{3}$, which rcduced low-frequency background current noise, perhaps stabilizing the seal between the pipette and the cell membrane (Nakao and Gadsby, 1989). Each experimental manipulation was carried out in both the presence and absence of $\mathrm{LaCl}_{3} \cdot \mathrm{La}^{3+}$, a general cation conductance blocker, did not reduce or enhance $\mathrm{Cl}^{-}$ currents measured under any circumstances in our experiments. Pipette solution osmolarity was $\sim 280 \mathrm{mOsm}$, and bath solutions were $\sim 290$ mOsm, unless indicated otherwise. Solution osmolarity was monitored using a vapor pressure osmometer (model 5500, Wescor, Logan, ITT.)

Electrophysiology. Voltage-clamp experiments were carried out using the tight-seal, whole-cell variant of the patch-clamp technique as described by Hamill et al. (1981). Patch pipettes were fabricated from thin-walled borosilicate glass (outer diameter $1.5 \mathrm{~mm}$, inner diameter $0.86 \mathrm{~mm}$; A-M Systems, Everett, WA) and fire-polished immediately before recording to an inner lip diameter of $1-2 \mathrm{~mm}$. In most experiments, pipettes were filled with a solution in which permeant monovalent cations were replaced by the relatively large, impermeant cation $N$-methyl-D-glucamine (NMDG), and a substantial fraction of permeant $\mathrm{Cl}^{-}$was replaced with the relatively impermeable anion gluconate (see Solutions). Electrodes filled with this solution had resistances of $1.2 \pm$ $0.04 \mathrm{M} \Omega(n=117)$.

Glass coverslips containing cells at nonconfluent density were placed in a Leiden coverslip dish mounted into a movable open perfusion microincubator (Medical Systems, Greenvale, NY) on an inverted Leitz microscope equipped with phase-contrast optics. Whole-cell currents were obtaincd using an Axopatch $200 \mathrm{~A}$ integrating patch-clamp amplifier (Axon Instruments, Foster City, CA). Cell membrane voltage was stepped from $-100 \mathrm{mV}$ to $+100 \mathrm{mV}$ in $20 \mathrm{mV}$ increments from a holding potential of $-80 \mathrm{mV}$. Voltage pulses were $820 \mathrm{msec}$ in duration and were delivered once every second. The output of the current-to-voltage converter was lowpass filtered at $300 \mathrm{~Hz}$ and then digitally sampled at $625 \mathrm{~Hz}$ by a Digidata $1200 \mathrm{~A} / \mathrm{D}$ converter (Axon Instruments) interfaced with an IBM-compatible computer (AST Premmia 4/66d). Voltage-clamp proto- 

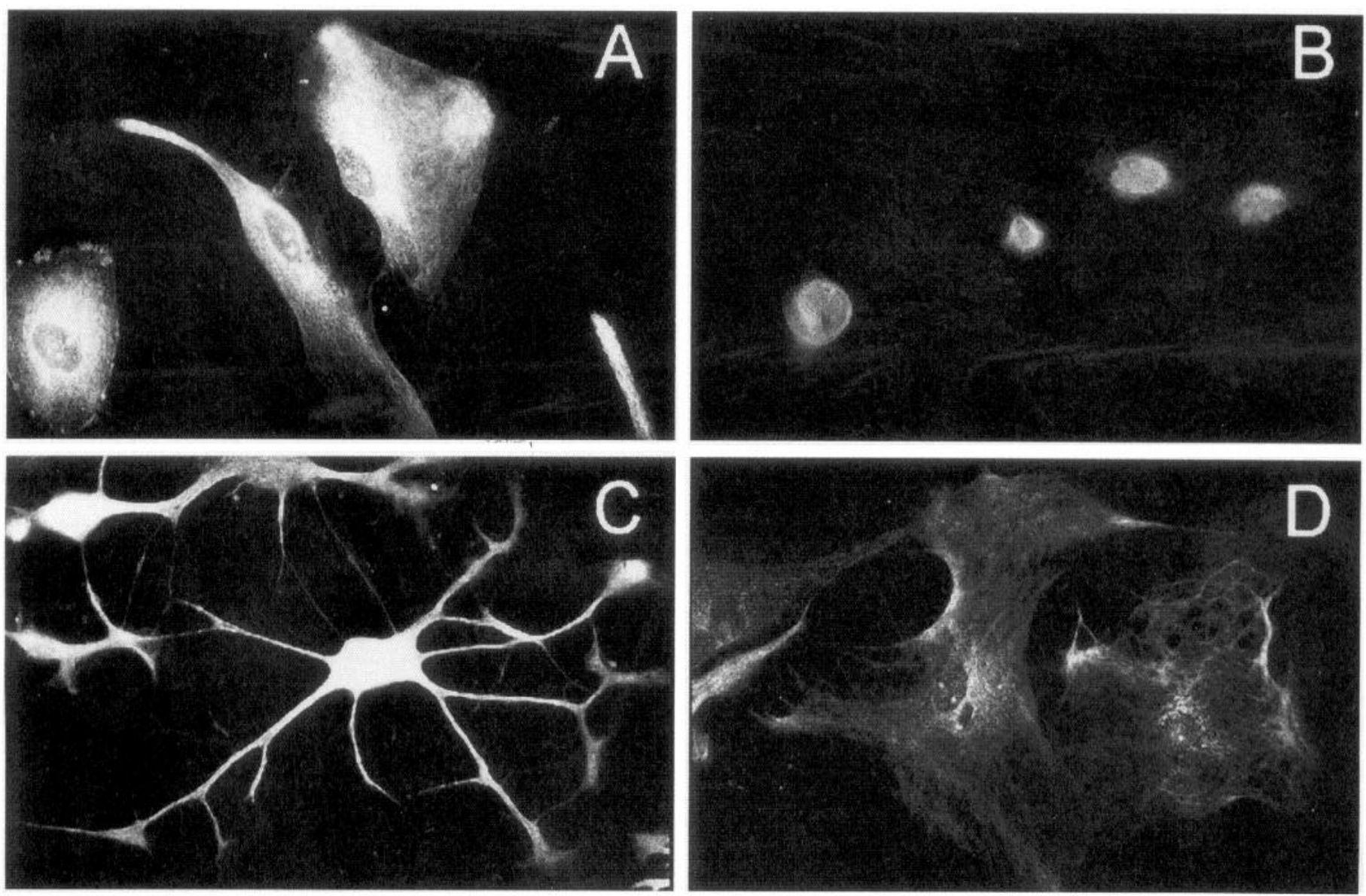

Figure 1. Four astrocytic morphologies in cerebral cortical cultures. $A$, Astrocytes are from a control culture, grown in serum-containing DMEM. Cells were fixed and labeled with a rabbit antiserum to GFAP followed by a rhodamine-conjugated anti-rabbit Ig antibody. The cells have a flat, polygonal morphology. B, Astrocytes were exposed to $0.025 \%$ trypsin in a divalent cation-free HBSS for $2-5$ min and then stained for GFAP. The cells appear as rounded-up spheres $10-20 \mu \mathrm{M}$ in diameter. $C$, Astrocytes were incubated in a standard Ringer's solution $\left(140 \mathrm{NaCl}, 10 \mathrm{~mm}\right.$ dextrose) for $>1 \mathrm{hr}$ at $37^{\circ} \mathrm{C}$ and labeled with anti-GFAP as above. The morphological transformation included cytoplasmic retraction, rounding-up of the cell body, and the formation of multipolar processes. These changes were most dramatic in cells $3-12 \mathrm{~d}$ after secondary plating and when fresh media was given $24 \mathrm{hr}$ before incubation. $D$, Astrocytes were osmotically swollen by exposure to hypotonic media ( $185 \mathrm{vs} 290 \mathrm{mOsm})$ and stained for GFAP. Total magnification is $387 \times$ for each image.

col, data acquisition, storage, and analysis were performed using the pClamp software suite (Axon Instruments).

Cells were equilibrated in bath recording solution before recording. After membrane rupture, large, voltage-dependent $\mathrm{K}^{+}$currents (Bevan et al., 1985) were either absent or rapidly decayed to zero in $<30 \mathrm{sec}$ as NMDG was exchanged for residual monovalent cations. All ions and pharmacological reagents used were of a MW $<1000$; complete exchange of reagents was assumed to take place within 2-3 min (Pusch and Neher, 1988). The start of experiments after membrane rupture was therefore delayed $3 \mathrm{~min}$. To avoid subtracting out ohmic regions of chloride current, currents were neither leak- nor capacity-corrected. Capacitance (CAP) and series resistance (SR), however, were monitored frequently throughout experiments to ensure adequate exchange of ions and pharmacological agents as well as to avoid the confounding influence that changing CAP and SR may have on current amplitudes and reversal potentials. CAP and SR estimates were obtained using the compensation circuits on the Axopatch 200A. In cells with little whole-cell current, CAP was also measured by integrating the current during a $20 \mathrm{mV}$ voltage step and subtracting a baseline established $\sim 15 \mathrm{msec}$ after the step $(n=10)$. These measurements indicated that there was $<5 \%$ error between the values obtained off the amplifier and those calculated from the charging transients. To minimize junction potential errors, $1 \mathrm{M} \mathrm{KCl}$ agar bridges were used as grounds and were refreshed frequently. Solution changes produced a $<3 \mathrm{mV}$ junction potential, and therefore correction of data for junction potential offsets was not performed.

Statistics. Data were expressed as mean \pm SEM, unless otherwise noted. Student's $t$ test for one population was used to evaluate significance for single groups with respect to zero. Student's independent $t$ test for two populations was used to evaluate significance between groups.
Materials. All salts and pharmacological reagents were purchased from Sigma (St. Louis, MO). Fetal calf serum for culture media was obtained from Gibco (Grand Island, NY).

\section{RESULTS}

\section{Astrocyte morphology}

Four astrocytic morphologies were studied for expression of $\mathrm{Cl}^{-}$ currents. The first pattern, the control morphology, was seen in cells as they were cultured in the presence of serum-containing DMEM. These cells were flat, thinly spread out, and polygonally shaped when plated either in plastic tissue culture flasks or on glass coverslips. The cells stained positively for GFAP and negatively for A2B5 and are illustrated in Figure $1 A$. The second pattern consisted of cells "rounded up" by briefly (3-5 min) exposing cells to divalent cation-free HBSS containing $0.025 \%$ trypsin. The cells, still attached to coverslips, appeared as crinkled spheres $10-20 \mathrm{~mm}$ in diameter (Fig. 1B). The third pattern, a multipolar process-bearing morphology ("stellate"), was obtained by incubating astrocytes in serum-free Ringer's solution warmed to $37^{\circ} \mathrm{C}$ for at least $1 \mathrm{hr}$ (Fig. $1 \mathrm{C}$ ). This shape, similar to astrocyte morphology in vivo, also has been described for astrocytes cocultured with neurons (Hatten, 1985) or treated with cAMP analogs such as dibutyryl cAMP (dBcAMP) (Lim et al., 1976), phorbol esters (Mobley et al., 1986), or the kinase inhibitors staurosporine 
(Mobley et al., 1994) and H7 (Bedoy and Mobley, 1989). After exposure to warm Ringer's solution, these cells underwent retraction of cytoplasm and process elongation as early as $20 \mathrm{~min}$ after exposure, with most cells transformed within 1-3 hr. The rate of morphological transformation was fastest when DMEM was refreshed 24 hr before incubation in Ringer's solution that was made fresh the same day, and it did not depend on whether a HEPES or a $\mathrm{HCO}_{3} / \mathrm{CO}_{2}$ system was used to buffer $\mathrm{pH}$. The fourth shape change comprised cells osmotically swelled by exposure to hypotonic solution (Fig. $1 D$ ). The recording solution, normally set at $290 \mathrm{mOsm}$, was made hypo-osmotic ( $185 \mathrm{mOsm})$ by diluting the NMDG-Cl component.

\section{$\mathrm{Cl}^{-}$currents are not present in flat astrocytes}

To determine whether rat ncocortical astrocytes in culture expressed whole-cell $\mathrm{Cl}^{-}$currents, pipette and bath recording solutions were designed to eliminate the contribution of monovalent cation currents. Thus all bath and pipette $\mathrm{K}^{+}$and $\mathrm{Na}^{+}$was replaced with the large impermeant cation $\mathrm{NMDG}^{+}$. We also used bath and pipette solutions with asymmetrical $\left[\mathrm{Cl}^{-}\right](140 \mathrm{~mm}$, bath; $40 \mathrm{~mm}$, pipette) to distinguish leakage currents from $\mathrm{Cl}^{-}$ conductance. The $\mathrm{Cl}^{-}$current reversal potential approximated by the Nernst relationship was $-31 \mathrm{mV}$. In these solutions, wholecell patching for up to $45 \mathrm{~min}$ of flat, polygonal astrocytes in culture revealed no significant conductance of any kind $(n=26)$ (Fig. 2). Our criteria for a null conductance was a maximum current amplitude of $<100 \mathrm{pA}$ at a membrane potential of 100 $\mathrm{mV}$. Cell input resistance in flat, polygonal astrocytes was usually $>1.5 \mathrm{G} \Omega$.

\section{$\mathrm{Cl}^{-}$currents are present in rounded-up cells}

The absence of detectable $\mathrm{Cl}^{-}$currents corroborated several reports examining whole-cell conductances in cultured astrocytes (Nowak et al., 1987; Barres et al., 1990a; Corvalan et al., 1990), but did not support the observation by Bevan et al. (1985) and Gray and Ritchie (1986) of a whole-cell, 4,4diisothiocyanostilbene-2,2'-disulfonic acid (DIDS)-sensitive $\mathrm{Cl}^{-}$ current in neocortical astrocytes. They described their current as voltage-gated, activated at potentials more positive than -40 to $-50 \mathrm{mV}$, and virtually abolished on replacement of $\mathrm{Cl}^{-}$with the large anion gluconate. In their experiments, astrocytes were rounded up by exposing the cells to a trypsin-containing divalent cation-free solution with EDTA for 2-5 min to facilitate wholecell patching. We reproduced more closely these conditions by exposing normally flat astrocytes to divalent cation-free HBSS containing $0.025 \%$ trypsin before introducing cells to the recording bath. In these balled-up astrocytes, we observed in 17 of 18 cells outwardly rectifying whole-cell $\mathrm{Cl}^{-}$currents with an average peak amplitude of $420 \pm 73 \mathrm{pA}($ range $=110-1112 \mathrm{pA} ; n=17)$ at $+100 \mathrm{mV}$ and an average current reversal potential of $-28.0 \pm$ $0.8 \mathrm{mV}(n=17)$ (Fig. 3). The current reversal of this conductance shifted $90 \%$ of the predicted Nernst for $\mathrm{Cl}^{-}$when bath $\left[\mathrm{Cl}^{-}\right]$was changed to $40 \mathrm{~mm}(0.2 \pm 2.7 \mathrm{mV} ; n=4)$ and $75 \%$ when the $\left[\mathrm{Cl}^{-}\right]$ was $8 \mathrm{mM}(24.8 \pm 2.3 ; n=5)$ by replacement of $\mathrm{Cl}^{-}$with gluconate (Fig. $3 B$ ). The current was inhibited significantly by 1 тм $7 n^{2+}(n=3)$ and $200 \mu \mathrm{M}$ DIDS $(n=3)$ (Fig. 7), both known anion channel blockers (Hille, 1992).

One notable difference between our results and those of Gray and Ritchie (1986) was the apparent voltage independence of our chloride currents. Although we observed an outward rectification when the bath and pipette contained 140 $\mathrm{mm}\left[\mathrm{Cl}^{-}\right]$and $40 \mathrm{~mm}\left[\mathrm{Cl}^{-}\right]$, respectively, the whole-cell cur-
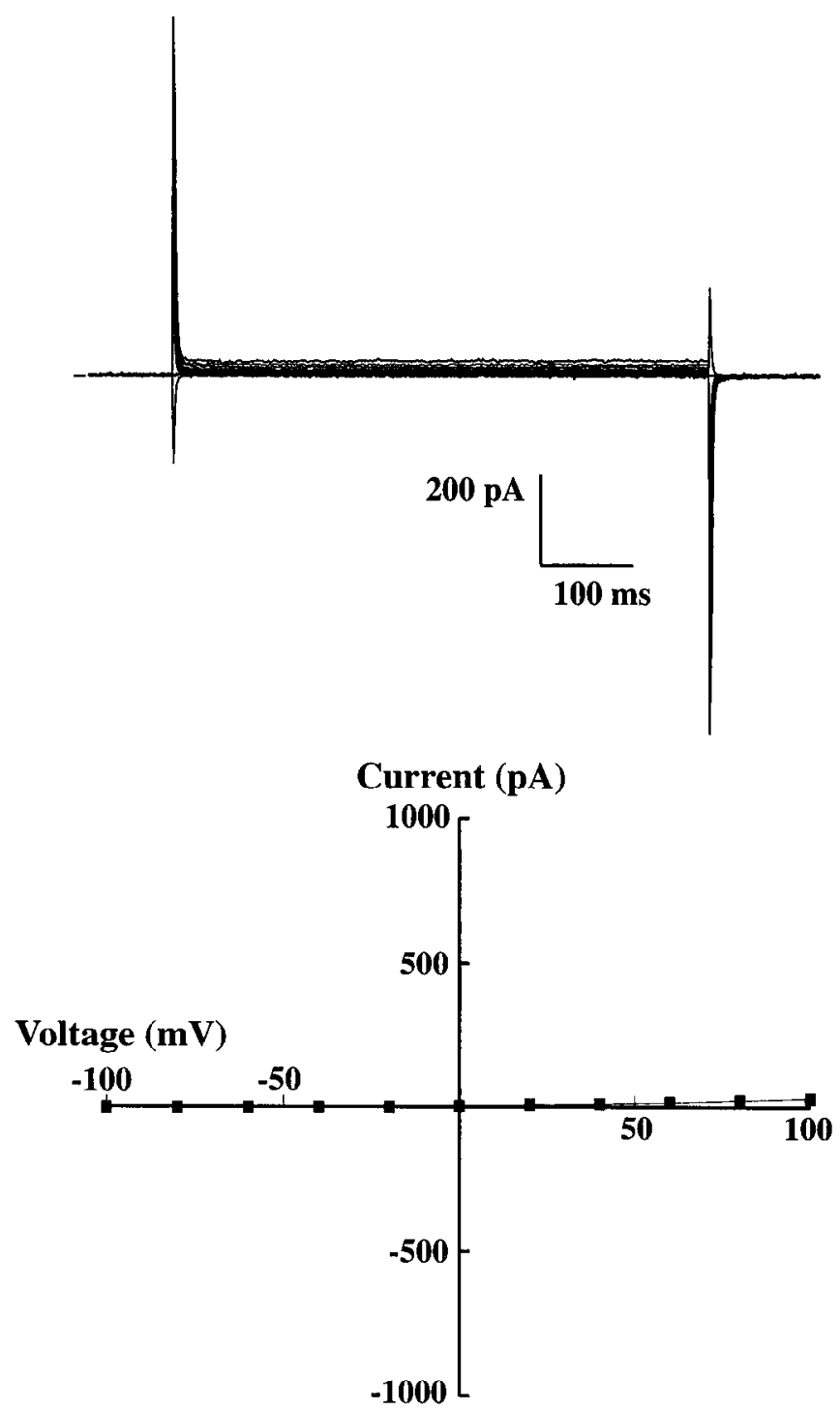

Figure 2. Cells from control cultures do not cxprcss whole-cell $\mathrm{Cl}^{-}$ currents. $\mathrm{Cl}^{-}$currents were not expressed in flat, polygonal astrocytes introduced directly into recording solutions from serum-containing DMEM $(n=26)$. The bath and pipette recording solutions were designed to eliminate cation currents by replacing all monovalent cations with NMDG. Cell membrane potential was stepped from $-100 \mathrm{mV}$ to $100 \mathrm{mV}$ in $20 \mathrm{mV}$ increments. Astrocytes expressing "no conductance" were defined as those cells exhibiting a peak current amplitude of $<100 \mathrm{pA}$ at 100 $\mathrm{mV}$. In flat, control astrocytes, input resistance with NMDG-Cl bath and pipette solutions was typically $>1.5 \mathrm{G} \Omega$.

rent-voltage $(I-V)$ became linear when the bath and pipette $\left[\mathrm{Cl}^{-}\right]$both equaled $40 \mathrm{~mm}$ (Fig. $3 B$ ). When the bath $\left[\mathrm{Cl}^{-}\right]$was reduced further to $8 \mathrm{~mm}$, the whole-cell current usually became inwardly rectifying (Fig. $3 B$ ). This behavior of outward and then inward rectification is what may be expected for the asymmetrical distribution of a permeable species as predicted by the constant field equation (Goldman, 1943). Although we did record some heterogeneity in the degree of relative outward to inward rectification (Fig. 6), we always observed a linear $I-V$ relationship when bath and pipette solutions were symmetrical at $40 \mathrm{~mm}\left[\mathrm{Cl}^{-}\right]$. This suggests a predominantly ohmic rather than a voltage-gated conductance. 


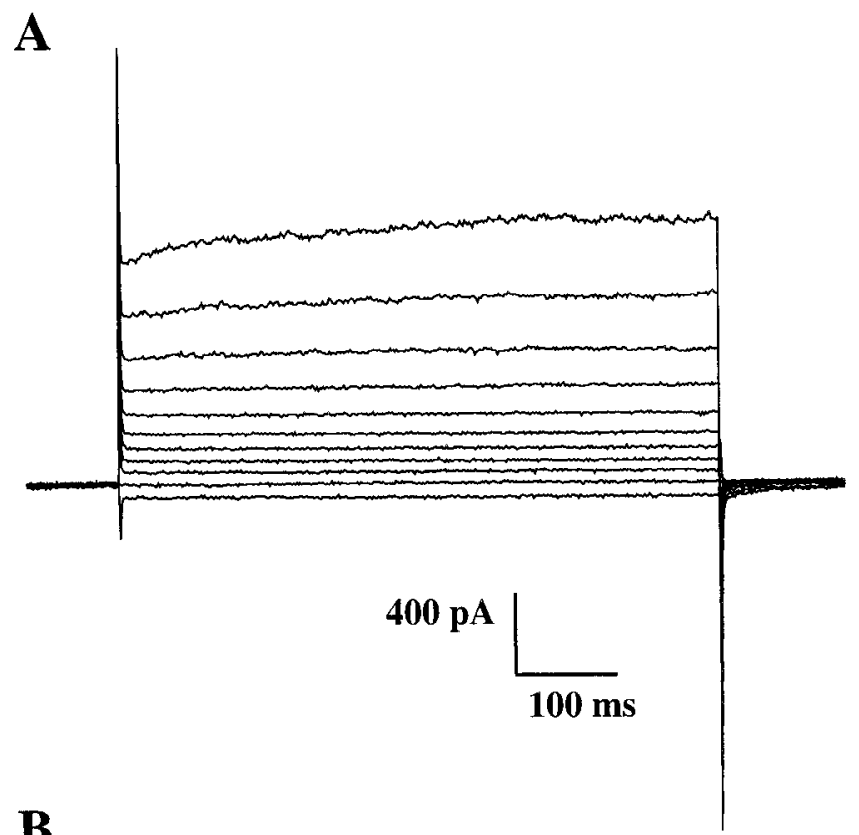

B

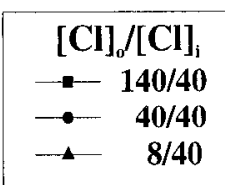

\section{Current (pA)}

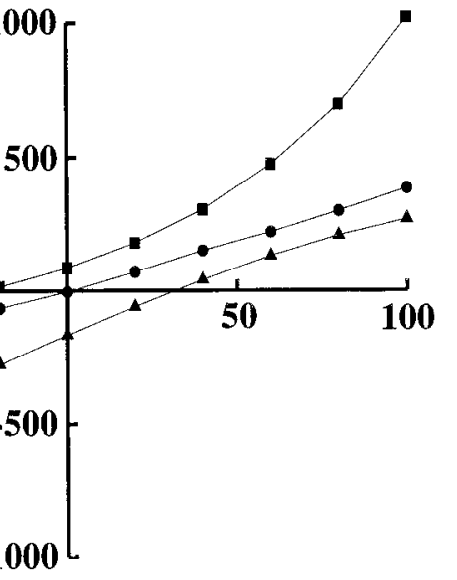

Figure 3. Induction of whole-cell $\mathrm{Cl}^{-}$currents after cell rounding. $A$, After exposure to $0.025 \%$ trypsin in divalent cation-free HBSS, 17 of 18 cells expressed outwardly rectifying whole-cell $\mathrm{Cl}^{-}$currents in asymmetrical solutions $\left(\left[\mathrm{Cl}^{-}\right]=40 \mathrm{~mm}\right.$ in the pipette; $140 \mathrm{~mm}$ in the bath). The average peak amplitude at $100 \mathrm{mV}$ was $420 \pm 73 \mathrm{pA}(n=17)$. $B$, The $I-V$ relationships of whole-cell $\mathrm{Cl}^{-}$currents when pipette $\left[\mathrm{Cl}^{-}\right]$was $40 \mathrm{~mm}$ and

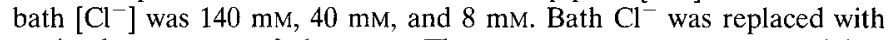
equimolar amounts of gluconate. The average zero-current potential at $140 \mathrm{~mm}(\square)$ was $-28.0 \pm 0.8 \mathrm{mV}(n-17)$, at $40 \mathrm{~mm}(\bullet)$ was $0.2 \perp 2.7$ $\mathrm{mV}(n=4)$, and at $8 \mathrm{mM}(\boldsymbol{\Delta})$ was $24.8 \pm 2.3 \mathrm{mV}(n=5)$. At each concentration, $I-V$ profiles were outwardly rectifying, linear, and inwardly rectifying, respectively.

\section{$\mathrm{Ca}^{2+}$ rarely activates $\mathrm{Cl}^{-}$current in control astrocytes}

We next investigated potential mechanisms for $\mathrm{Cl}^{-}$current activation after cell rounding-up. We first tested whether the $\mathrm{Cl}^{-}$ conductance was $\mathrm{Ca}^{2+}$-activated, because we suspected that astroglial $\left[\mathrm{Ca}^{2+}\right]_{\mathrm{i}}$ increased significantly after first exposure to $\mathrm{Ca}^{2+}$ free solution (with trypsin) and then reexposure to media with 2.0 $\mathrm{mM}\left[\mathrm{Ca}^{2+}\right]$ (our recording solution). $\mathrm{Ca}^{2+}$ removal followed by $\mathrm{Ca}^{2+}$ replacement produces a "calcium paradox" in astrocytes and other cells (Uemura et al., 1985; Kim-Lee et al., 1992) in which $\left[\mathrm{Ca}^{2+}\right]_{\mathrm{i}}$ levels increase dramatically above their original resting baseline. $\mathrm{Ca}^{2+}$ has been shown to activate $\mathrm{Cl}^{-}$channels via calmodulin kinase II (Holevinsky et al., 1994) as well as directly in oocytes (Miledi and Parker, 1984). In addition, activation of protein kinase $\mathrm{C}$, most isoforms of which are $\mathrm{Ca}^{2+}$-dependent, has also been demonstrated to induce $\mathrm{Cl}^{-}$currents (Schumann and Raffin, 1994). In recordings lasting up to $30 \mathrm{~min}$, we observed detectable $\mathrm{Cl}^{-}$currents when palching with a pipette $\left[\mathrm{Ca}^{2+}\right]$ buffered to $2000 \mathrm{~nm}$ in only 2 of 15 flat astrocytes (13\%, as compared with $94 \%$ of rounded-up cells; data not shown). This result suggested that although $\mathrm{Ca}^{2+}$ may have a role in activating $\mathrm{Cl}^{-}$currents, elevated $\mathrm{Ca}^{2+}$ alone was usually insufficient, and other additional intracellular factors might be involved in current expression.

\section{Stellate astrocytes express $\mathrm{Cl}^{-}$current}

We also tested for activation by protcin kinasc $\mathrm{C}$ by exposing cells to $1 \mu \mathrm{M}$ phorbol 12-myristate 13-acetate (PMA) in serum-free Ringer's solution at $37^{\circ} \mathrm{C}$ for $1 \mathrm{hr}$. After this incubation, we observed in four of five cells outwardly rectifying $\mathrm{Cl}^{-}$currents (595 \pm 283 pA, data not shown). Yet when we pretreated cells with PMA and staurosporine, a general kinase inhibitor, we also observed $\mathrm{Cl}^{-}$current in four of four cells (471 $\pm 189 \mathrm{pA}$, data not shown). Finally, when we ran the control, incubating the cells in Ringer's solution alone with no PMA or staurosporine at $37^{\circ} \mathrm{C}$ for $1 \mathrm{hr}$, the next five cells also exhibited outwardly rectifying wholecell $\mathrm{Cl}^{-}$currents (data included in a larger set below) (Fig. 4).

In the PMA and PMA plus staurosporine-treated populations, and in the control population incubated in Ringer's solution alone, the astrocytes had undergone dramatic morphological changes. Cells changed from a flat, polygonal morphology to one in which the cell body was rounded up with multiple processes (Fig. $1 C$ ). In cells transformed by exposure to only warm Ringcr's solution, cell capacitance (as an approximation of cell size) ranged from 23 to $>100 \mathrm{pF}$ with a mean of $61 \pm 21 \mathrm{pF}(n=46)$. Thus these transformed cells varied in size and on the whole were large. In 46 cells exposed to warm Ringer's solution alone, $89 \%$ (41 of 46) of process-bearing astrocytes expressed whole-cell $\mathrm{Cl}^{-}$currents (Fig. 4), with a mean peak amplitude of $598 \pm 77 \mathrm{pA}$ (range - 111-1935 pA) at $+100 \mathrm{mV}$. Amplitude correlated poorly with cell capacitance ( $r=0.25$, by least squares linear regression). The current reversal potential for these cells was $-29.9 \pm 0.8 \mathrm{mV}(n$ $=5$ ) with $140 \mathrm{~mm}\left[\mathrm{Cl}^{-}\right]$in the bath and $40 \mathrm{~mm}\left[\mathrm{Cl}^{-}\right]$in the pipette. With $40 \mathrm{~mm}\left[\mathrm{Cl}^{-}\right]$in both the bath and pipette, the reversal potential was $8.6 \pm 2.2 \mathrm{mV}(n=5)$, and the $I-V$ was again linear (Fig. $4 B$ ). With $8 \mathrm{~mm}\left[\mathrm{Cl}^{-}\right]$in the bath, the reversal depolarized to $31 \pm 2.6 \mathrm{mV}(n=4)$, and the $I-V$ became inwardly rectifying (Fig. $4 B$ ). These currents were also significantly inhibited by $1 \mathrm{~mm} \mathrm{Zn}^{2+}(n=3)$ as well as $200 \mu \mathrm{M}$ DIDS $(n=3)$ (Fig. 7).

\section{Swelling activates $\mathrm{Cl}^{-}$current}

Although a role for second messenger systems in $\mathrm{Cl}^{-}$current activation in both rounded-up and stellate astrocytes could not be ruled out, no obvious $\mathrm{Ca}^{2+}$-dependent messenger system or kinase pathway seemed to be required through activation by direct increases in $\left[\mathrm{Ca}^{2+}\right]_{i}$ or application of pharmacological agents. The property that hoth the "balled up" and the process-bearing astrocytes shared was significant change in cell shape. We therefore investigated whether another cell structural perturbation, osmotic swelling, could also elicit $\mathrm{Cl}^{-}$current. After exposure to a recording solution with a reduced osmolarity of 185 mOsm (normally $290 \mathrm{mOsm}$ ), 8 of 10 cells expressed whole-cell Cl${ }^{-}$currents with a mean peak amplitude similar to that in rounded-up and trans- 
A

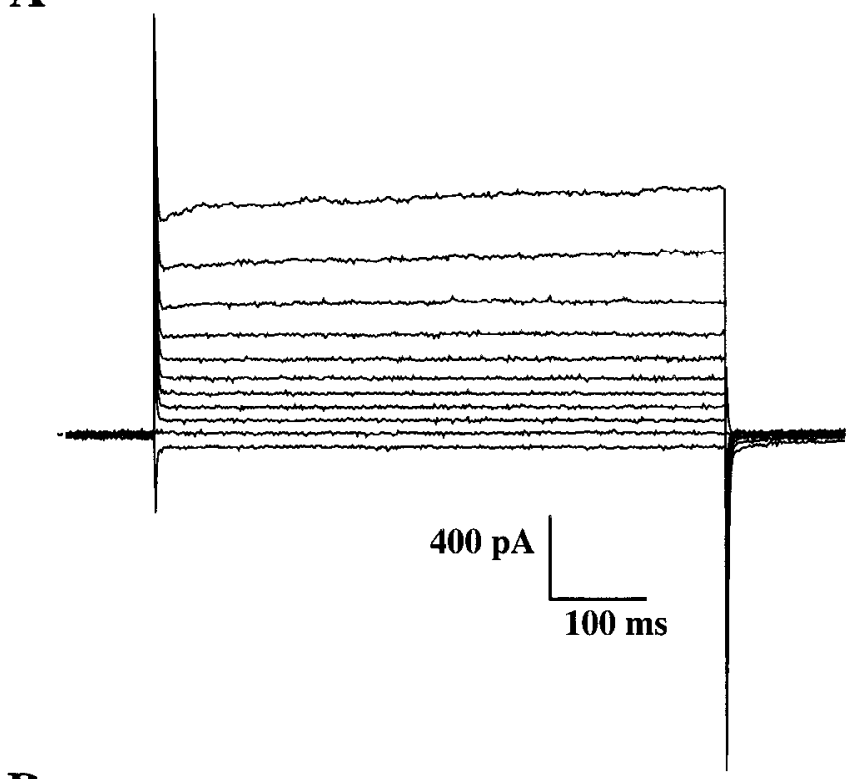

B

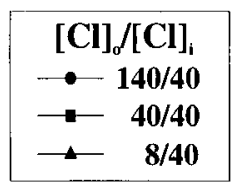

\section{Current (pA)}

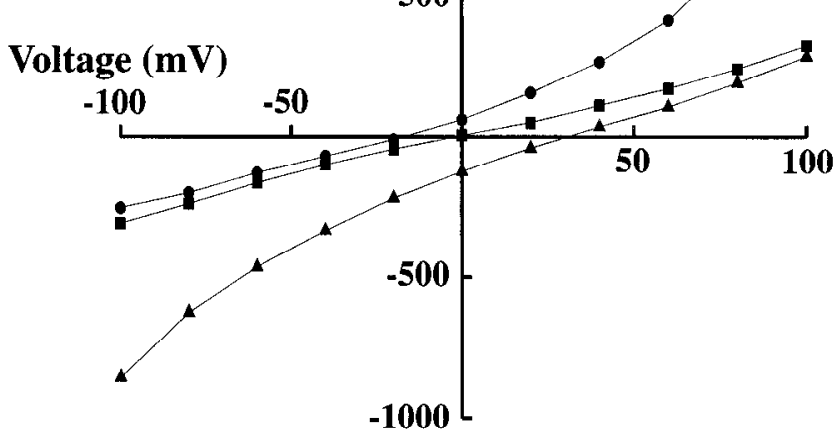

Figure 4. Stellate astrocytes express $\mathrm{Cl}^{-}$currents. $A$, After incubating flat astrocytes in Ringer's solution for $>1$ hr at $37^{\circ} \mathrm{C}$, cells were transformed into a process-bearing morphology, and $89 \%$ (41 of 46 cells) expressed whole-cell $\mathrm{Cl}^{-}$currents with an average peak amplitude at $100 \mathrm{mV}$ of 598 $\pm 77 \mathrm{pA}(n=41)$. Expression did not depend on activation by protein kinase $\mathrm{C}$ using phorbol esters (PMA), on the presence of the kinase inhibitor staurosporine, or on whether a bicarbonate or a HEPES-based buffer system was used. $B, I-V$ profiles at different bath $\left[\mathrm{Cl}^{-}\right]$, generated as in Figure 3. The zero-current potential at $140 \mathrm{~mm}(\bullet)$ was $-29.9 \pm 0.8$ $\mathrm{IIV}(n=41)$, al $40 \mathrm{~mm}(\mathbb{\square})$ was $8.6 \pm 2.2(n=5)$, and al $8 \mathrm{~mm}(\Delta)$ was $31 \pm 2.6 \mathrm{mV}(n=4)$. As with the rounded-up cells, the $I-V$ is rectifying in asymmetrical solutions and linear when bath and pipette $\left[\mathrm{Cl}^{-}\right]$are both $40 \mathrm{~mm}$.

formed cells $(410 \pm 101 \mathrm{pA} ; n=8)$ (Fig. 5). Bath osmolarity was reduced by selectively diluting the NMDG-Cl component of the bath, and $\left[\mathrm{Ca}^{2+}\right],\left[\mathrm{Mg}^{2+}\right]$, and [HEPES] were kept constant. The current reversal followed the Nernst prediction when the concentrations of bath NMDG and $\mathrm{Cl}^{-}$were returned to $140 \mathrm{mM}(-30.0$ $\pm 1.8 \mathrm{mV} ; n=8$ ) (Fig. $5 B$ ). When the bath [NMDG] and $\left[\mathrm{Cl}^{-}\right]$ was reduced but supplemented with sucrose to maintain osmolar-
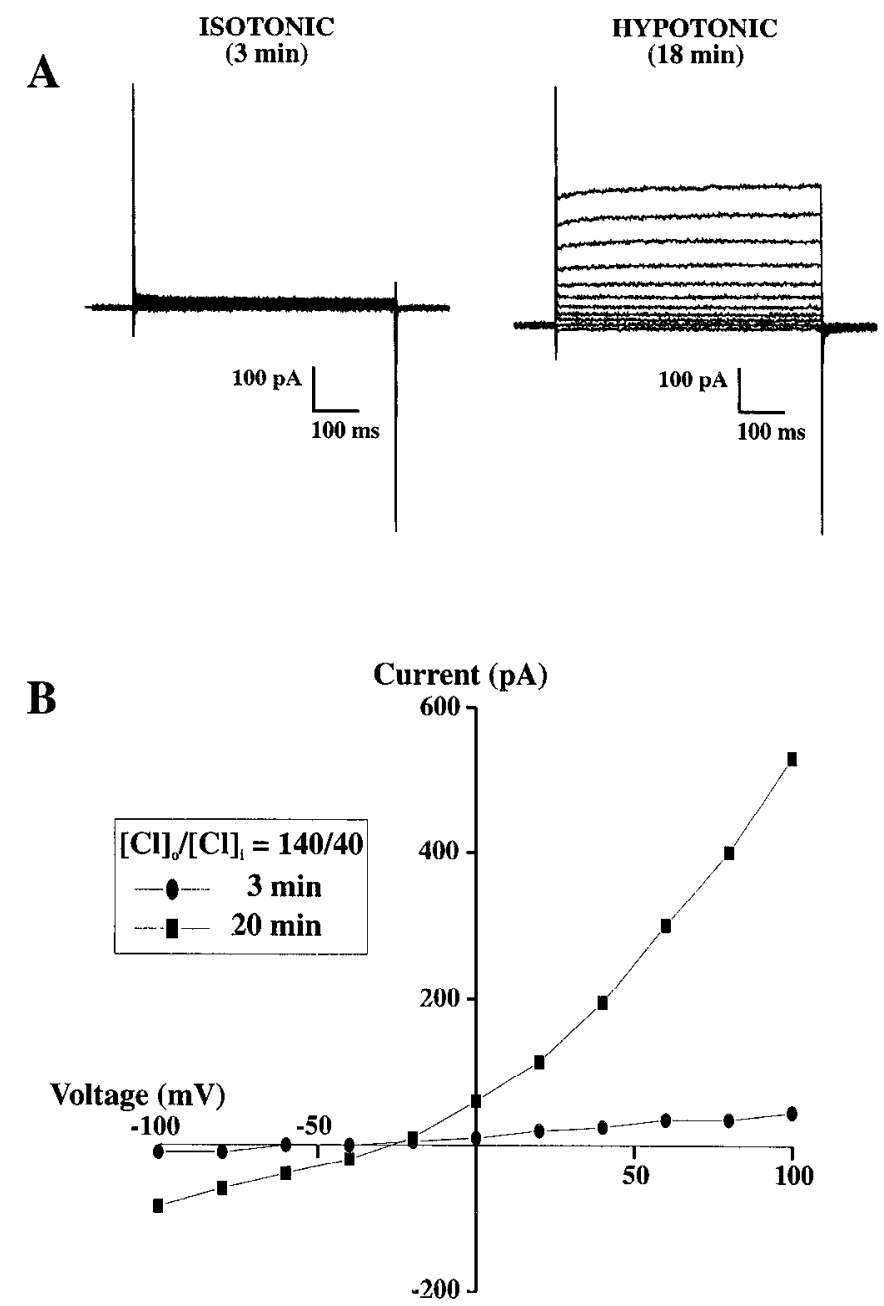

Figure 5. Cell swelling activates a $\mathrm{Cl}^{-}$conductance. $A$, Whole-cell $\mathrm{Cl}^{-}$ currents were present in 8 of 10 cells exposed to hypotonic $(185 \mathrm{mOsm}$; normally $290 \mathrm{mOsm}$ ) recording solutions. Bath osmolarity was reduced by selectively diluting the NMDG-Cl component of the bath solution while maintaining $\left[\mathrm{Ca}^{2+}\right],\left[\mathrm{Mg}^{2+}\right]$, and [HEPES]. The average peak amplitude in 8 cells was $410 \pm 101 \mathrm{pA}$ after the bath solution was changed back to 290 mOsm (140 mM NMDG-Cl). $B$, The whole-cell currents at $140 \mathrm{~mm}$ bath $\left[\mathrm{Cl}^{-}\right](\square)$ were outwardly rectifying, and the average zero-current potential was $-30.0 \pm 1.8 \mathrm{mV}(n=8)$. Filled ovals indicate cells $3 \mathrm{~min}$ after whole-cell configuration was achieved and before osmotic change.

ity, no current was evident ( $n=5$, data not shown). The swellingactivated current also shared the same $\mathrm{Zn}^{2+}(n=3)$ and DIDS $(n$ $=3$ ) pharmacology as the $\mathrm{Cl}^{-}$currents expressed in the balled-up and process-bearing astrocytes described above (Fig. 7).

\section{Heterogeneity of chloride currents}

In all three morphological paradigms, i.e., rounded up, process bearing, and osmotically swelled, we observed variability in both voltage- and time-dependent activation and inactivation. As illustrated from the current traces of three cells in Figure $6 \mathrm{~A}$, current kinetics could vary from a delayed activation (left-hand current trace in Fig. 6A) to an instantaneous, time-independent activation (middle record in Fig. 6A). Although activation in most cells of all three morphologies tended toward time-independent activation, different cells expressed activation kinetics along the entire spectrum, from instantaneous to delayed. In addition, activation ki- 

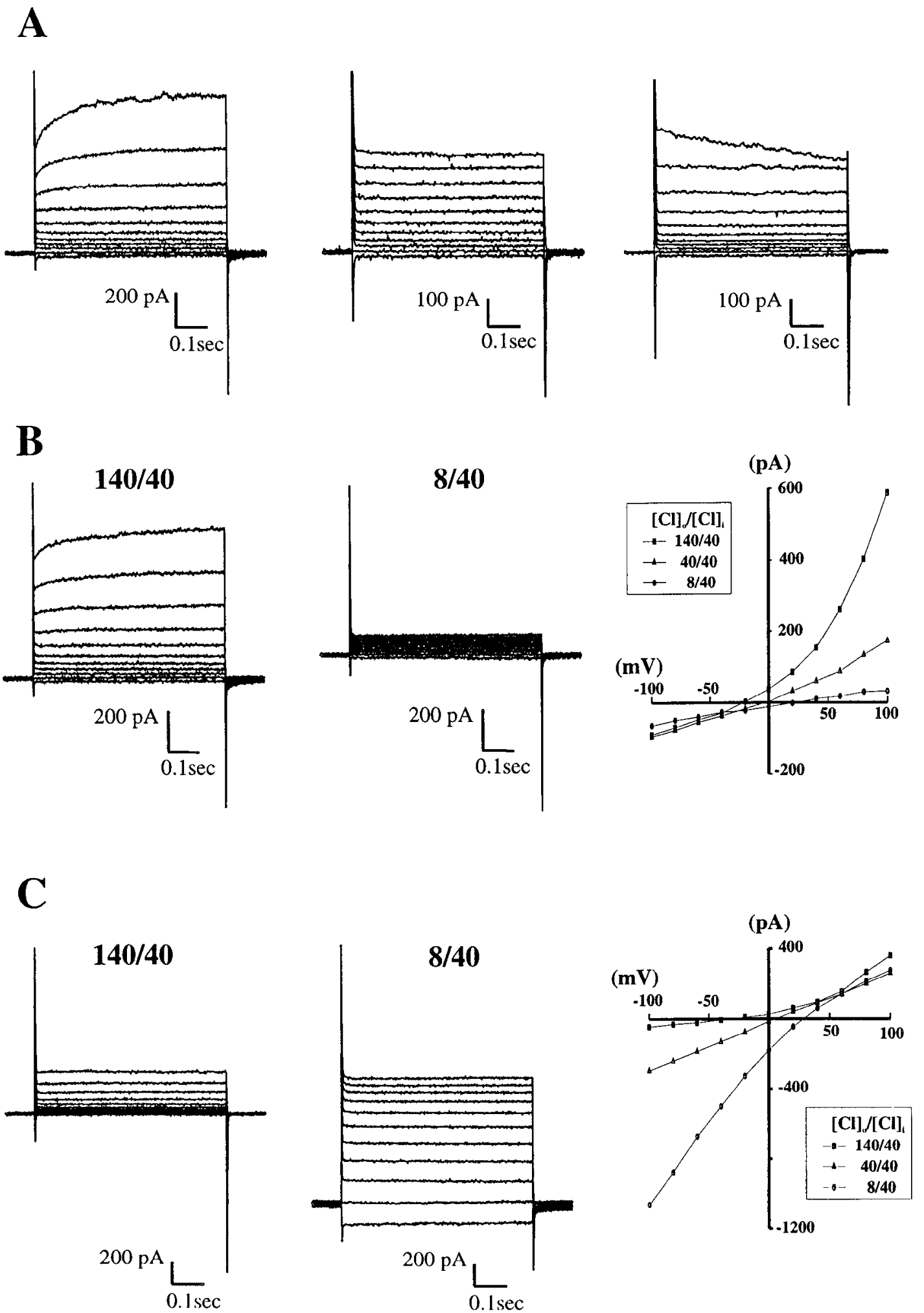

Figure 6. Heterogeneity of astroglial $\mathrm{Cl}^{-}$currents. $A$, Variability in the kinetics of current activation and inactivation were seen in each morphological paradigm. The left-hand profile shows whole-cell currents with a delayed activation, most apparent at depolarized potentials. The middle and right traces demonstrate currents with instantaneous activation. The right trace, as compared with the middle and left-hand traces, shows depolarization-dependent inactivation, most evident at $100 \mathrm{mV}$. Variability in activation and inactivation kinetics could be seen within single cells and across cells in each morphology. Each variation was seen in every cell shape in which $\mathrm{Cl}^{-}$currents were expressed. $B$ and $C$, Variability was also observed in the degree of outward relative to inward rectification when zero-current potentials were examined by replacing bath $\mathrm{Cl}^{-}$with gluconate. These observations were made in rounded-up and stellate cells. Although the absolute magnitudes of outward relative to inward rectification were usually approximately equal, the cell in $B$ demonstrates an extreme example of dominant outward rectification, and the cell in $C$ demonstrates the most extreme example of dominant inward rectification. 


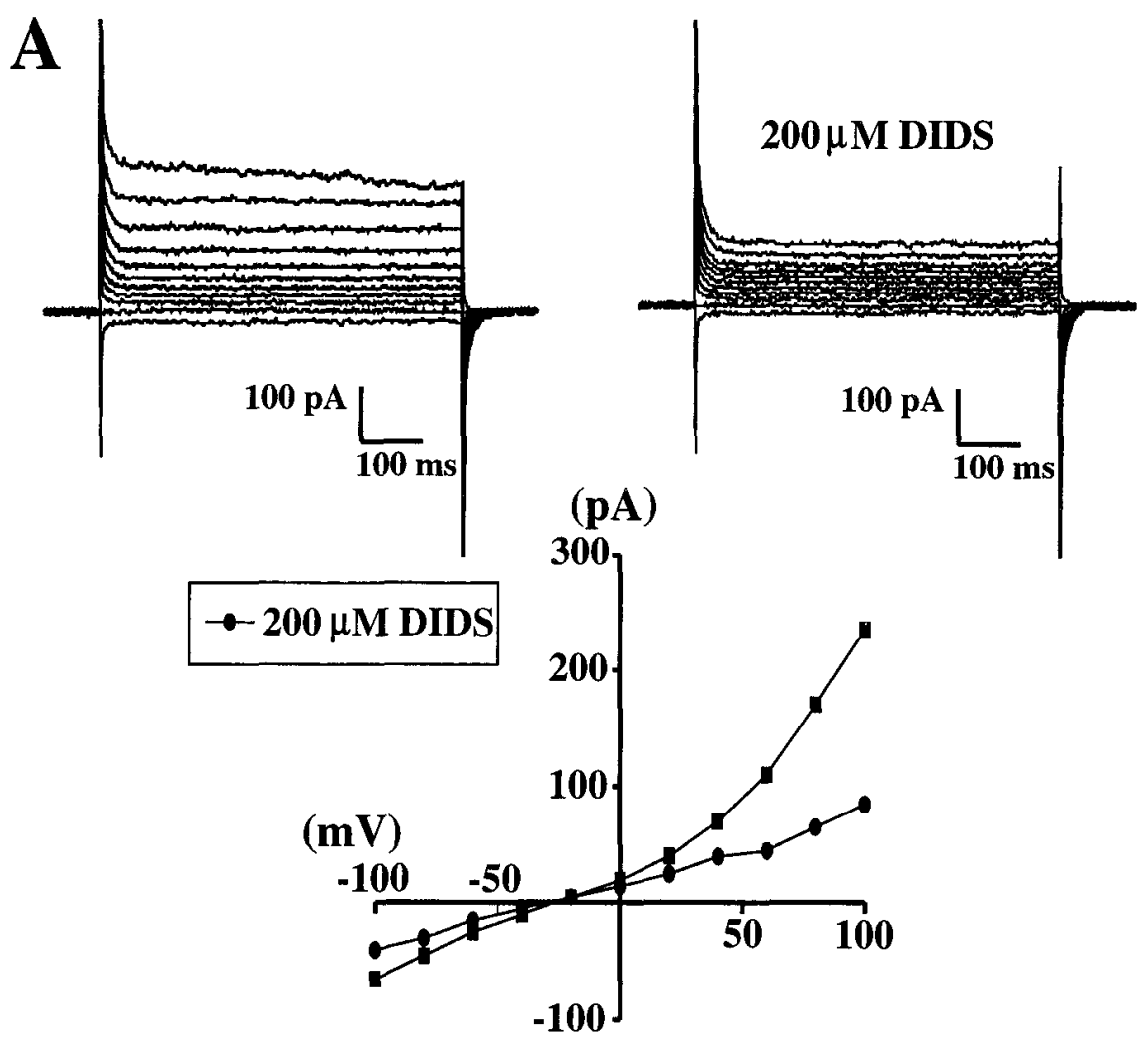

B

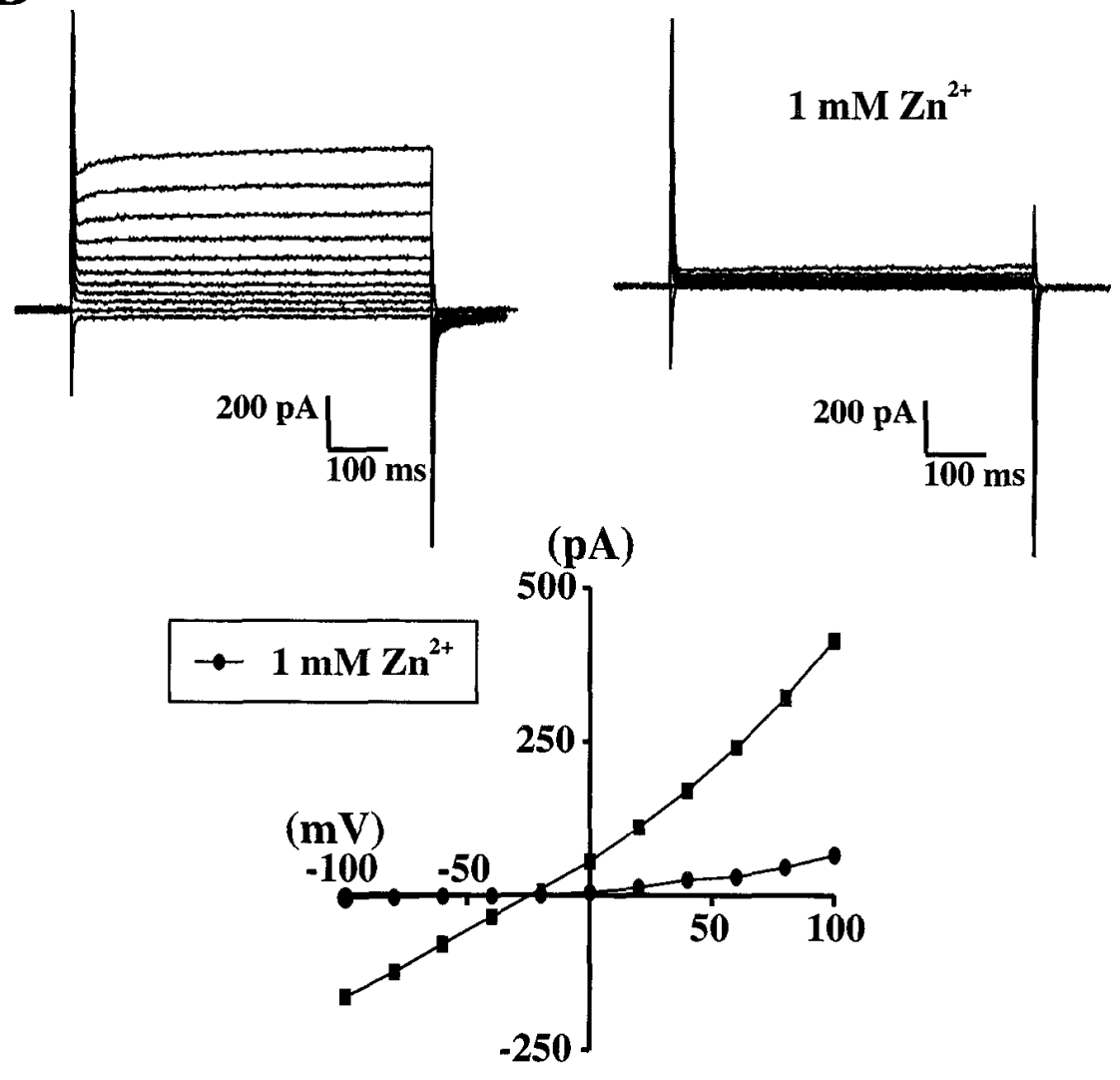

Figure 7. $\mathrm{Cl}^{-}$currents are inhibited by $\mathrm{Zn}^{2+}$ and DIDS. $A$, Whole-cell $\mathrm{Cl}^{-}$currents expressed in each experimental condition were inhibited $74 \pm$ $12 \% ; n=12$ ) by $200 \mu \mathrm{M}$ DIDS. Peak $I-V$ relationship in a stellate cell before (更) and after (0) application of DIDS. $B, \mathrm{Cl}^{-}$currents were also blocked $(87 \pm 5 \% ; n=12)$ by $1 \mathrm{mM} \mathrm{Zn}^{2+}$. Peak $I-V$ profile for a stellate cell before $(\square)$ and after (ब) $\mathrm{Zn}^{2+}$ application. The pharmacology was the same across experimental paradigms. DIDS block was only partially reversible, whereas $\mathrm{Zn}^{2+}$ block was completely reversible 5-10 min after washout. 
netics could shift within a single cell over time, with the shift in current kinetics almost always from delayed activating to timeindependent. We also observed a time-dependent delayed inactivation at depolarized potentials in 10-20\% of cells from all three paradigms (Fig. 6A, right-hand current trace). Again, as with activation, there was considerable variability in the degree of timedependent inactivation, and the degree of inactivation could shift during recording, most often from no inactivation to considerable inactivation at +80 to $+100 \mathrm{mV}$. Depolarization and timedependent inactivation in swelling-induced $\mathrm{Cl}^{-}$currents in rat glioma cells has been studied recently in detail (Jackson and Strànge, 1995).

Another type of heterogeneity in current profiles became evident as we sequentially reduced bath $\left[\mathrm{Cl}^{-}\right]$while recording from rounded-up and process-bearing astrocytes. Although the $I-V$ profiles were always linear when bath and pipette $\left[\mathrm{Cl}^{-}\right]$were both $40 \mathrm{~mm}$, the degree of outward rectification relative to inward rectification varied from cell to cell when the bath $\left[\mathrm{Cl}^{-}\right]$was either $140 \mathrm{~mm}$ or $8 \mathrm{~mm}$. The two extremes are illustrated in Figure $6 B, C$. Thus some cells had a dominant outward rectification when the bath $\left[\mathrm{Cl}^{-}\right]$was $140 \mathrm{~mm}$ and virtually no inward rectification at 8 mM $\left[\mathrm{Cl}^{-}\right]$(Fig. $6 B$ ), even as the zero-current potential accurately followed the predicted Nernst ${ }_{\mathrm{Cl}-}$. In other cells the opposite held (Fig. 6C), with the relative magnitude of inward rectifying current at $8 \mathrm{~mm}$ bath $\left[\mathrm{Cl}^{-}\right]$greater than the magnitude of outward rectifying current at $140 \mathrm{~mm}\left[\mathrm{Cl}^{-}\right]$. This type of heterogeneity, as well as that in activation and inactivation kinetics, suggests (1) an underlying diversity in astrocytic $\mathrm{Cl}^{-}$channels and/or (2) a homogenous population of channels at different states of modulation, perhaps via different degrees of phosphorylation.

\section{Cytoskeletal actin and $\mathrm{Cl}^{-}$currents}

When astrocytes undergo cytoplasmic retraction, cell-body rounding, and process development and elongation after exposure to cAMP analogs, these shape changes are associated with the rapid depolymerization and breakdown of actin (Goldman and Abramson, 1990; Baorto et al., 1992). Although our cells were not cxposed to cAMP analogs, the morphological changes after exposure to serum-free Ringer's solution were similar to those reported after incubation with dBcAMP or agents such as forskolin (Barres et al., 1989), which activate adenylate cyclase. This evidence, combined with that demonstrating a role for actin depolymerization in cell swelling (for review, see Mills et al., 1994) and in the modulation of $\mathrm{Ca}^{2+}$ (Johnson and Byerly, 1993), NMDA (Rosenmund and Westbrook, 1993), $\mathrm{Na}^{+}$(Cantiello et al., 1991), and $\mathrm{Cl}^{-}$channel activity (Schwicbert et al., 1994) led us to test the hypothesis that depolymerization of cytoskeletal actin mediates the expression of $\mathrm{Cl}^{-}$currents accompanying changes in astrocytic morphology.

Inclusion of $5 \mu \mathrm{M}$ cytochalasin B $(n=6)$, cytochalasin D $(n=$ $4)$, or dihydrocytochalasin B $(n=3)$, which depolymerizes actin by augmenting actin-AT'P hydrolysis (Sampath and Pollard, 1991), elicited whole-cell $\mathrm{Cl}^{-}$currents in flat, polygonal control cells otherwise not expressing any significant conductance (Fig. 8). Average peak current amplitude pooled for all cytochalasins used was $420 \pm 108(n=13)$, and the zero-current potential was -28.4 $\pm 0.9 \mathrm{mV}$. In most cells, $\mathrm{Cl}^{-}$current was evident within $3 \mathrm{~min}$ after achieving the whole-cell configuration and usually became maximal 10-20 min after the start of the experiment. Differences in the time course of activation may be attributable to cell-to-cell variability in access resistance as well as cell size. Better estimates of the kinetics of depolymerization and conductance activation
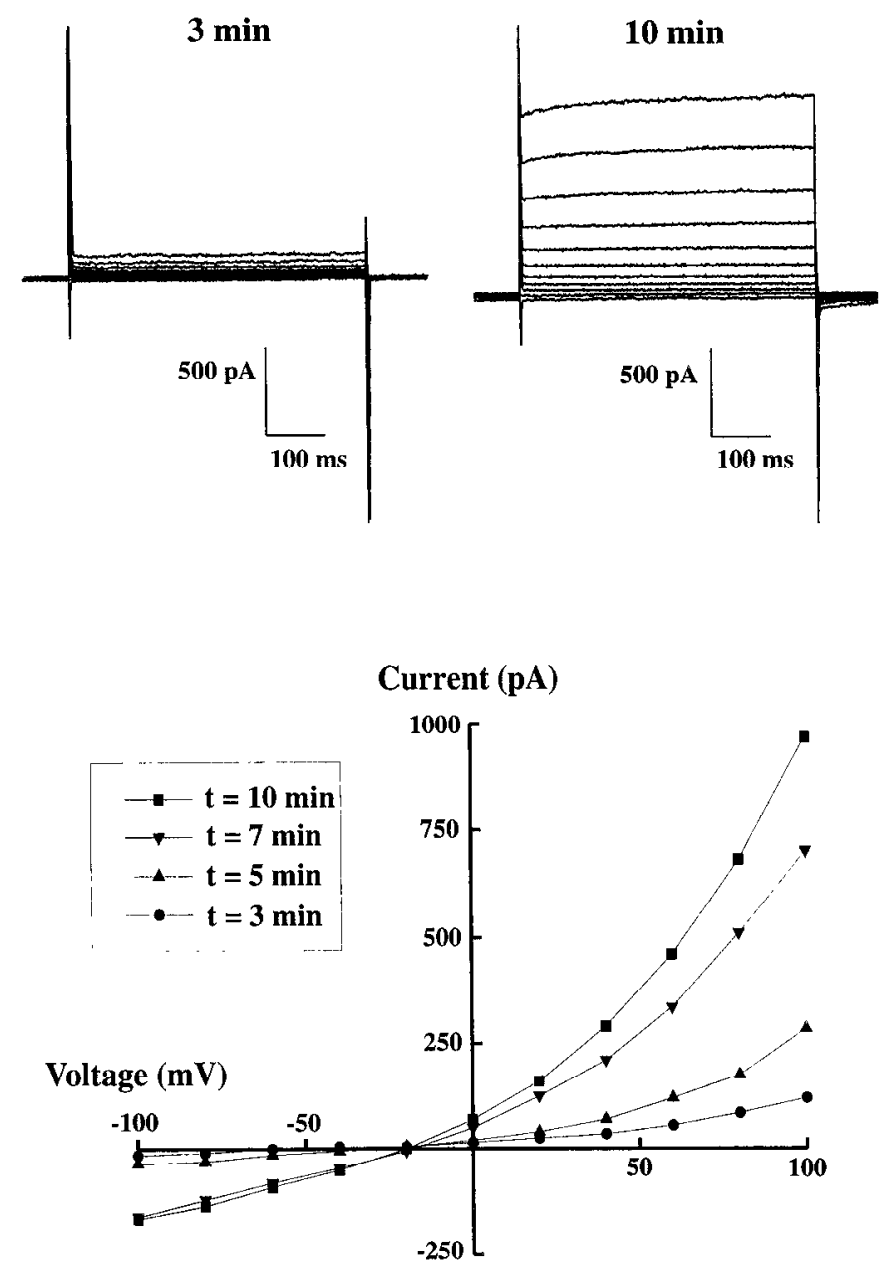

Figure 8. Cytochalasins activate $\mathrm{Cl}^{-}$currents in control astrocytes. Whole-cell $\mathrm{Cl}^{-}$currents were elicited in flat, polygonal cells when dialyzed with $5 \mu \mathrm{M}$ cytochalasin $\mathrm{B}(n=6)$, cytochalasin $\mathrm{D}(n=4)$, and dihydrocytochalasin B $(n=3)$. Average peak current amplitude for all cytochalasin-treated cells was $420 \pm 108 \mathrm{pA}(n=13)$, comparable to the peak amplitude of $\mathrm{Cl}^{-}$currents in each morphological transformation. The mean zero-current potential for all cells was $-28.4 \pm 0.9 \mathrm{mV}$. Some $\mathrm{Cl}^{-}$current was usually evident $3 \mathrm{~min}$ after going whole-cell and became maximal 10-20 min after the start of the recordings. The cell in this figure expressed peak current at 10 min after the start of the experiment with 5 $\mu \mathrm{M}$ cytochalasin $\mathrm{B}$.

are more likely to be obtained in experiments in which drugs are applied directly to excised patches expressing dormant channels.

In cells, the actin cytoskeleton can be regulated dynamically, with increases in intracellular $\mathrm{Ca}^{2+}$ rapidly depolymerizing filamentous actin (F-actin) and ATP (along with other cellular molecules) inducing repolymerization (Pollard and Cooper, 1986). Although in flat, polygonal astrocytes, elevated intracellular $\mathrm{Ca}^{2+}$ alone was rarely sufficient to activate $\mathrm{Cl}^{-}$current, elevated $\left[\mathrm{Ca}^{2+}\right]$ in stellate cells dramatically enhanced $\mathrm{Cl}^{-}$currents already present by $187 \pm 47 \%(n=10)$ (Fig. $9 A)$. The enhancement seemed to be actin-dependent, because co-inclusion in the pipette of $1 \mu \mathrm{M}$ phalloidin, which binds and stabilizes F-actin, significantly inhibited the $\mathrm{Ca}^{2+}$-induced increase in current $(n=8 ; p<0.005)$ (Fig. $9 A$ ). The percentage current change $(-8 \% \pm 5 \%)$ from zero with phalloidin was insignificant $(p=0.17$ ) (Fig. 9A). Additionally, $5 \mathrm{~mm}$ ATP in the pipette produced a decrease in $\mathrm{Cl}$ current in stellate cells of $44 \pm 10 \%(n=8)$ (see Fig. $9 B$ ) and was 
A

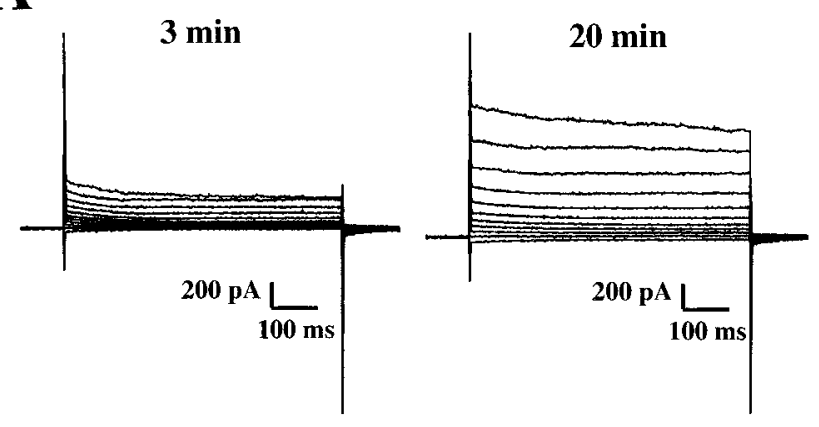

B

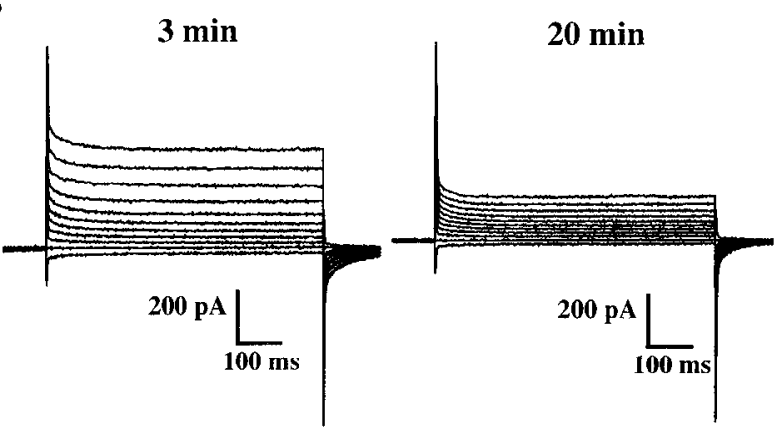

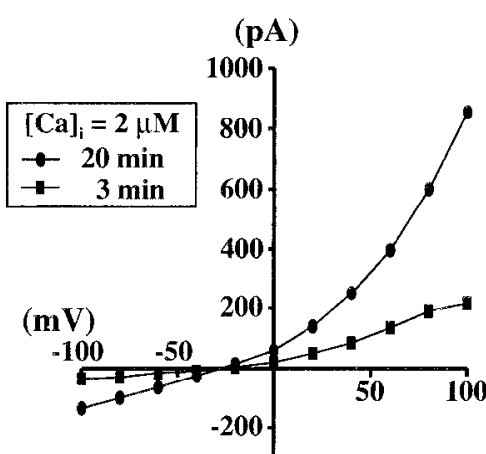
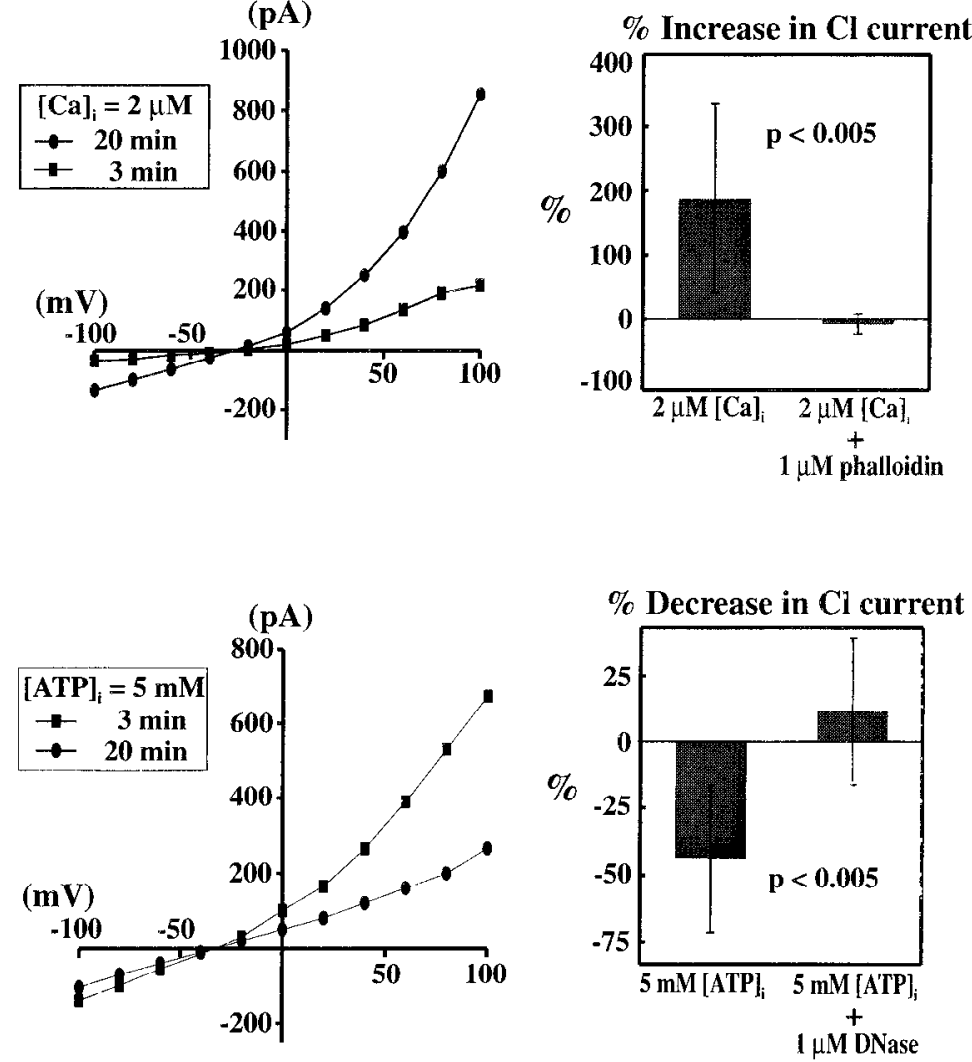

Figure 9. Actin-dependent modulation of $\mathrm{Cl}^{-}$currents by $\mathrm{Ca}^{2+}$ and ATP in stellate cells. $A$, In stellate cells already expressing $\mathrm{Cl}^{*}$ currents, pipette Ca ${ }^{2+}$ buffered to $2 \mu \mathrm{M}$ amplified $\mathrm{Cl}^{-}$currents by $187 \pm 47 \%(p<0.005 ; n=10)$ during 20 min of recording $(\bullet)$. This amplification was blocked by co-inclusion of $1 \mu \mathrm{M}$ phalloidin in the pipette $(p<0.005 ; n=8)$. Percentage current change from zero $(-8 \pm 5 \%)$ with phalloidin in the pipette was insignificant $(p$ $=0.17)$. $B$, In stellate cells, $5 \mu \mathrm{M}$ pipette ATP significantly reduced $\mathrm{Cl}^{-}$currents by $44 \pm 10 \%(p<0.005 ; n=8)(\bullet)$ over 20 min. This effect of ATP was blocked by co-inclusion with bovine DNaseI $(p<0.005 ; n=5)$. Percentage current change from zero $(11 \pm 7 \%)$ with DNaseI in the pipette was insignificant $(p=0.19)$.

prevented significantly by codialysis with DNaseI $(n=5 ; p<$ 0.005 ) (see Fig. $9 B$ ), which binds tightly to monomeric actin and inhibits polymerization (Kabsch and Vandekerckhove, 1992). The percentage current change from zero $(11 \pm 7 \%)$ with DnaseI was insignificant $\left(p=0.19\right.$ ) (Fig. 9B). The effects of $\mathrm{Ca}^{2+}$ and ATP, and their prevention by agents that bind actin, suggest strongly that astrocytic $\mathrm{Cl}^{-}$current can be modulated dynamically by changes in intracellular $\mathrm{Ca}^{2+}$ and cell metabolism acting through the actin cytoskeleton.

Finally, we were also able to block osmotically induced $\mathrm{Cl}^{-}$ currents in astrocytes by cell dialysis with $1 \mu \mathrm{M}$ phalloidin before exposing cells to hypotonic recording solutions ( $n=5$; data not shown). This effect of phalloidin on osmotically activated wholecell $\mathrm{Cl}^{-}$currents has becn observed recently in renal cells (Schweibert et al., 1994).

\section{Actin cytochemistry}

We stained cytoskeletal F-actin in astrocytes using an FITCconjugate of phalloidin (Faulstich et al., 1988) to provide parallel evidence that the actin cytoskeleton is being altered in cells undergoing morphological changes. In flat untransformed control cells, the F-actin appears in a striking, well organized crisscrossing pattern of stress fibers that traverses the entire cell and intersect with the membrane (Fig. 10A). When the cells are rounded up by exposure to trypsin, this organized pattern of actin looks completely disrupted (Fig. 10B). The stress fibers are no longer evident, and stained F-actin seems to be collapsed around the nucleus. In cells that have been converted to stellate after exposure to warm Ringer's solution, the stress fiber pattern again looks disrupted, but not as dramatically (Fig. 10C). F-actin staining is diffuse throughout the cytoplasm, with remnants of the criss-crossing fibers still visible. Finally, flat control cells osmotically swelled also demonstrate a clear disruption of F-actin (Fig. $10 D$ ). Actin disruption after osmotic swelling has been show in other cell types as well (Hallows et al., 1991).

\section{DISCUSSION}

Our results demonstrate that astrocytic morphology can determine the expression of an electrogenic pathway for $\mathrm{Cl}^{-}$transport in culture. Furthermore, $\mathrm{Cl}^{-}$conductances can be open at astrocytic resting potentials, and cytoskeletal actin may have a major role, directly or indirectly, as a mechanism modulating $\mathrm{Cl}^{-}$channel expression in astrocytes. Finally, astroglial $\mathrm{Cl}^{-}$currents seem to be modulated by changes in $\left[\mathrm{Ca}^{2+}\right]_{i}$ and $[\mathrm{ATP}]_{\mathrm{i}}$, which in turn influence the polymerization status of actin. These results are significant because previous studies have shown that $\mathrm{Cl}^{-}$conductances are normally inactive in cultured astrocytes. Channel activity is observed only after excision of membrane patches. Current-clamp recordings (Kimelberg et al., 1979; MacVicar et al., 1989) and other whole-cell voltage clamp reports (Nowak et al., 1987; Barres et al., 1990a; Corvalan et al., 1990) support these single-channel studies. Several investigators have suggested that the removal of a constitutive inhibitor in astrocytes might be 

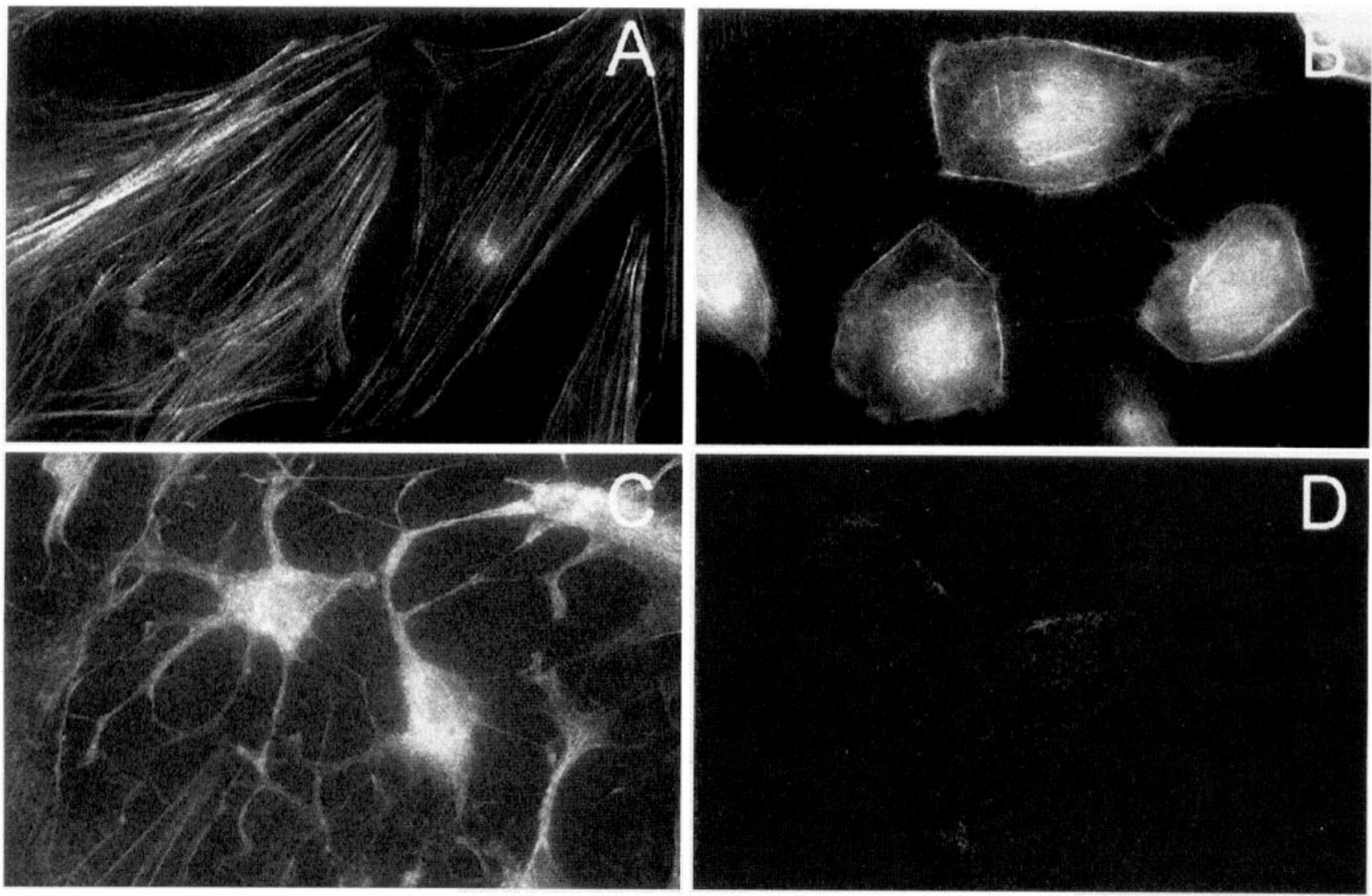

Figure 10. Actin breakdown accompanies morphological change. $A-D$, Cytoskeletal actin from each astrocytic morphology was examined using an FITC conjugate of phalloidin. $A$, Flat, polygonal control astrocytes demonstrate a well organized criss-crossing pattern of stress fibers that traverse the entire cell and meet beneath the membrane surface with cortical actin network parallel to the membrane. $B$, Cells rounded up by exposure to trypsin reveal a complete disruption of organized actin stress fibers. Polymerized actin seems to be present only around the nucleus and underneath the membrane. $C$, Stellate cells transformed from control by exposure to warm Ringer's solution also demonstrate a disruption of the well organized pattern of actin fibers seen in flat, polygonal astrocytes, although cytoplasmic actin polymers seem to be more diffusely present than in rounded-up cells. $D$, Cells exposed to hypotonic $(185 \mathrm{mOsm})$ recording bath for $10 \mathrm{~min}$ also demonstrate diffuse depolymerization of actin. Total magnification is $489 \times$ for each image.

necessary for $\mathrm{Cl}^{-}$current expression (Barres et al., 1990b). Our data suggest that polymerized actin may be part of an inhibitory mechanism suppressing channels in quiescent astrocytes. Changes in cell shape, through depolymerization of cytoskeletal actin, may activate normally suppressed $\mathrm{Cl}^{-}$channels.

\section{$\mathrm{Cl}^{-}$conductances and cytoskeletal actin}

Several reports now exist that demonstrate an interaction between actin depolymerization and ion channel activation. Cytochalasins activate a stretch- and swelling-sensitive large-conductance anion channel in a renal cell line (Schwiebert et al., 1994); RVD and $\mathrm{K}^{+}$ channel activation depend on the presence of an actin-binding protein in melanoma cells (Cantiello et al., 1993), and disruption of F-actin activates $\mathrm{Na}^{+}$channels in A6 cells (Cantiello et al., 1991). Cytochalasins also increase the open probability of an intermediate $\mathrm{Cl}^{-}$channel in skeletal muscle cells (Haussler et al., 1994) and potentiate the activation of a volume-regulated $\mathrm{Cl}^{-}$ conductance in B-lymphocytes (Levitan et al., 1995). Depolymerization of actin may also be associated with channel rundown and inactivation, however, as has been shown for $\mathrm{Cl}^{-}$channels (Suzuki et al., 1993), NMDA channels (Rosenmund and Westbrook, 1993), and $\mathrm{Ca}^{2+}$ channels (Johnson and Byerly, 1993). The mechanisms by which actin may be influencing channel function are unknown in each case.
In astrocytes, actin breakdown may liberate an inhibitory molecule or allow access of an activating factor or channel-containing vesicles destined to be inserted into the membrane. Polymerized actin could also interact directly with $\mathrm{Cl}^{-}$channels, inhibiting activity by changing channel conformation or phosphorylating channel proteins via kinases associated with actin polymers; however, actin may also interact with channels indirectly through other cytoskeletal elements. Several studies have shown that ion channels and transporters are structurally linked to actin through spectrin and ankyrin (Drenckhahn et al., 1985; Nelson and Veshnock, 1987; Srinivasan et al., 1988). Whether these linkages affect the function of these proteins is not known. At present, our data do not provide any mechanistic answers linking actin depolymerization to $\mathrm{Cl}^{-}$channel activation.

\section{Chloride channels underlying chloride conductances}

Gray and Ritchie (1986) described their whole-cell $\mathrm{Cl}^{-}$currents as reflecting a population of voltage-gated $\mathrm{Cl}^{-}$channels activated at potentials between $-50 \mathrm{mV}$ and $-40 \mathrm{mV}$. We propose that the whole-cell $\mathrm{Cl}^{-}$currents in our rounded-up astrocytes (and also our stellate and swollen cells) are attributable to the same underlying channel population, but we believe this population is more ohmic than voltage-gated. In our experiments, $\mathrm{Cl}^{-}$current rectification most often approximated the prediction of the constant- 
field equation for a channel population at constant permeability (Goldman, 1943) and was notably absent when $\left[\mathrm{Cl}^{-}\right]_{\mathrm{i}}$ and $\left[\mathrm{Cl}^{-}\right]_{\mathrm{o}}$ were symmetrical. The differences between our results and those of Gray and Ritchie (1986) may be attributable to different voltage protocols; Gray and Ritchie used a leak current subtraction procedure. The effect of leak subtraction on $\mathrm{Cl}^{-}$conductances has been noted recently for swelling-activated $\mathrm{Cl}^{-}$currents in oocytes (Ackerman et al., 1994). Leak subtraction can greatly confound $I-V$ relationships, zero-current potentials, and steady-state current amplitudes over time if any portion of the $I-V$ relationship is linear, which we found to be the case with astroglial $\mathrm{Cl}^{-}$currents evèn in asymmetrical solutions. Therefore, our currents were not leak-subtracted.

The heterogeneity we observed in the kinetics of activation and inactivation suggests that multiple types of channels could underlie shape-dependent $\mathrm{Cl}^{-}$currents in astrocytes. A distribution of kinetic profiles similar to ours has been observed in oocytes (Ackerman et al., 1994), for example, apparently reflecting separate $\mathrm{Cl}^{-}$channel types. In addition, the heterogeneity of outward relative to inward rectification also suggests that rectifying (as compared with purely ohmic) $\mathrm{Cl}^{-}$channels may contribute variably to astroglial $\mathrm{Cl}^{-}$currents. Two rectifying $\mathrm{Cl}^{-}$channels have been identified in glial cells to date, both of which may contribute to shape-dependent $\mathrm{Cl}^{-}$currents. The $25-60 \mathrm{pS} \mathrm{Cl}$ channel observed by Barres et al. (1990a) in cultured optic nerve type-1 astrocytes is outwardly rectifying and has a significant open probability at both negative and positive potentials. The volumesensitive anion channel described by Jackson and Strange (1995) in C6 glioma cells is also outwardly rectifying and shares the feature of depolarization-dependent inactivation that we observe occasionally in our morphologically changed astrocytes. In addition, Ferroni et al. (1995) recently reported an inwardly rectifying $\mathrm{Cl}^{-}$conductance in astrocytes conditioned by long-term exposure to dibutyryl cAMP.

The purely ohmic component of astroglial $\mathrm{Cl}^{-}$currents could potentially arise from the large-conductance anion channels observed in excised patches from both rat and mouse neocortical astrocytes. The function of these channels with an open probability greatest around $0 \mathrm{mV}$ is not known for any cell type in which they have been observed, although Jalonen et al. (1993) suggested that the astrocytic channel serves as an "emergency" $\mathrm{Cl}^{-}$permeability pathway during massive depolarizations accompanying cell swelling. Two lines of evidence, however, suggest that these channels may function near high astrocytic resting potentials as well. First, Sonnhof (1987) noted that $10-15 \%$ of the large-conductance channels he observed were voltage-independent, active at all potentials from $-90 \mathrm{mV}$ to $90 \mathrm{mV}$. Second, asymmetrical $\mathrm{Cl}^{-}$solutions, with low $\mathrm{Cl}^{-}$on the intracellular face of the membrane, can shift the open probability curve of large-conductance anion channels by several tens of millivolts in the hyperpolarizing direction (Hals and Palade, 1990). In cultured astrocytes, $\left[\mathrm{Cl}^{-}\right]_{\mathrm{i}}$ is $20-40 \mathrm{~mm}$ (Kettenmann et al., 1987). In intact tissue, astroglial $\left[\mathrm{Cl}^{-}\right]_{\mathrm{i}}$ may be $<6 \mathrm{~mm}$ (Ballanyi et al., 1987), two orders of magnitude lower than $\left[\mathrm{Cl}^{-}\right]_{0}$. This $\mathrm{Cl}^{-}$asymmetry could render the entire population of large-conductance channels functional within a more typical range of high astrocyte membrane potentials. In addition, a brain-derived porin sharing many electrophysiological characteristics with large-conductance anion channels has been cloned recently and localized to astrocyte membranes (Dermietzel et al., 1994). Finally, the disruption of F-actin with cytochalasins or by swelling has been shown to activate a large-conductance $(305 \mathrm{pS}) \mathrm{Cl}^{-}$channel in a renal cell line (Schwiebert et al., 1994). The permeability properties, actindependence, and function of astrocytic large-conductance anion channels require further investigation.

\section{Significance of shape-dependent $\mathrm{Cl}^{-}$currents in astrocytes}

The induction and modulation of astroglial $\mathrm{Cl}^{-}$currents through actin depolymerization is likely to influence any process coupled to the movement of anions. One such process is astroglial $\mathrm{K}^{+}$ homeostasis. During the last 30 years, two competing hypotheses have emerged on how glia regulate extracellular $\mathrm{K}^{+}$. The first, a "spatial buffering" hypothesis, proposes that elevated $\mathrm{K}^{+}$is driven into $\mathrm{K}^{+}$-selective glial cells and shunted distally by an intraglial voltage gradient (Orkand et al., 1966; Newman, 1984). The second, a " $\mathrm{K}^{+}$accumulation" hypothesis, proposes the passive entry of $\mathrm{K}^{+}$into glia with anions following as countercharge (GardnerMedwin, 1980). In the latter scenario, $\mathrm{K}^{+}$is stored locally instead, and both uptake and storage necessitate anion permeability.

Several lines of evidence now suggest that $\mathrm{K}^{+}$accumulation may be the dominant mechanism by which extracellular $\mathrm{K}^{+}$is regulated. Elevations in intracellular $\mathrm{K}^{+}$in invertebrate and mammalian glia are accompanied by parallel increases in $\left[\mathrm{Cl}^{-}\right]_{i}$ (Ballanyi et al., 1987; Coles et al., 1989). $\mathrm{Cl}^{-}$-free solutions markedly impede $\mathrm{K}^{+}$uptake by glia and disrupt extracellular $\mathrm{K}^{+}$ regulation in the drone retina (Coles et al., 1989). Intraglial $\mathrm{Cl}^{-}$ measurements using ion-selective microelectrodes in guinea pig olfactory slices suggest that $\mathrm{Cl}^{-}$is distributed passively (Ballanyi et al., 1987). Finally, Gardner-Medwin (1980) and Barres et al. (1990a) argue that the length constant of adult astrocytes may be too short to support an intraglial voltage gradient sufficient for spatial buffering.

Barres et al. (1990b) have suggested that the $\mathrm{K}^{+}$accumulation mechanism dominates everywhere except in the retina, where a spatial buffer process is more anatomically feasible. Our data add support for the $\mathrm{K}^{+}$accumulation hypothesis by demonstrating a mechanism for $\mathrm{Cl}^{-}$permeability; however, our results also suggest that the ability of astrocytes to accumulate $\mathrm{K}^{+}$with $\mathrm{Cl}^{-}$or other anions such as bicarbonate (Kraig and Chesler, 1988) may vary. As seen in our stellate cells, a morphology that more closely resembles that in vivo, $\mathrm{Cl}^{-}$currents seem to be modulated by $\left[\mathrm{Ca}^{2+}\right]_{i}$ and $[\mathrm{A} T \mathrm{P}]_{i}$ acting through cytoskeletal actin. Perhaps with increased brain activity, elevations in astrocytic $\left[\mathrm{Ca}^{2+}\right]_{1}$ trigger an increased $\mathrm{Cl}^{-}$permeability via actin depolymerization that enhances the capacity of astrocytes to take up $\mathrm{K}^{+}$and store it locally. During periods when the brain is relatively quiescent, with $\left[\mathrm{Ca}^{2+}\right]_{\mathrm{i}}$ low, energy abundant, and actin more polymerized, astroglial $\mathrm{Cl}^{-}$conductances become markedly decreased, and small local increases in extracellular $\mathrm{K}^{+}$are more spatially buffered.

The modulation of astroglial $\mathrm{Cl}^{-}$currents is also likely to influence other anion-coupled processes, including $\mathrm{pH}$ and neurotransmitter homcostasis as wcll as the control of astrocyte cell volume. Neurotransmitter, $\mathrm{pH}$, and volume aberrations are thought to underlie many disease states in brain. Thus the relationship between structural changes, cytoskeletal alterations, and $\mathrm{Cl}^{-}$permeability changes is likely to be relevant for how astrocytes behave, not only in physiological but also in pathological contexts. Understanding this relationship could provide important clues about how astrocytes in these contexts interact dynamically with other brain cells and influence not 
only their own behavior but also the behavior of their environment.

\section{REFERENCES}

Ackerman MJ, Wickman KD, Clapham DE (1994) Hypotonicity activates a native chloride current in Xenopus oocytes. J Gen Physiol 103:153-179.

Anderson C (1994) Easy-to-alter digital images raises fear of tampering. Science 263:317-318.

Anderson BJ, Li X, Alcantara AA, Isaacs KR, Black JE, Greenough WT (1994) Glial hypertrophy is associated with synaptogenesis following motor-skill lcarning, but not with angiogencsis following exercise. Glia $11: 73-80$

Backus KH, Berger T, Kettenmann H (1991) Activation of neurokinin receptors modulates $\mathrm{K}$ and $\mathrm{Cl}$ channel activity in cultured astrocytes from rat cortex. Brain Res 541:103-109.

Ballanyi K, Grafe P, Bruggencate GT (1987) Ion activities and potassium uptake mechanisms of glial cells in guinea-pig olfactory cortex slices. J Physiol (Lond) 382:159-174.

Baorto DM, Mellado W, Shelanski ML (1992) Astrocyte process growth induction by actin breakdown. J Cell Biol 117:357-367.

Barres BA, Chun LLY, Corey DP (1989) Calcium current in cortical astrocytes: induction by cAMP and neurotransmitters and permissive effect of serum factors. J Neurosci 9:3159-3175.

Barres BA, Koroshetz WJ, Chun LLY, Corey DP (1990a) Ion channel expression by white matter glia: the type-1 astrocyte. Neuron 5:527-544.

Barres BA, Chun LLY, Corey DP (1990b) Ion channels in vertebrate glia. Annu Rev Neurosci 13:441-474.

Bedoy CA, Mobley PL (1989) Astrocyte morphology altered by 1-(5isoquinolinylsulfonyl) 2-methyl piperazine $(\mathrm{H}-7)$ and other protein kinase inhibitors. Brain Res 490:243-254.

Bevan S, Chiu SY, Gray PTA, Ritchie JM (1985) The presence of voltage-gated sodium, potassium and chloride channels in rat cultured astrocytes. Proc R Soc Lond [Biol] 225:299-313.

Cantiello HF, Prat AG, Bonventre JV, Cunningham CC, Hartwig J, Ausiello DA (1993) Actin-binding protein contributes to cell volume regulatory $i$ channel activation in melanoma cells. J Biol Chem 268:4596-4:

Cantiello HF, Stow J, Prat AG, Ausiello DA (1991) Actin filaments control epithelial Na channel activity. Am J Pliysiol 261:C882-C888.

Coles JA, Orkand RK, Yamate CL (1989) Chloride enters glial cells and photoreceptors in response to light stimulation in the retina of the honey bee drone. Glia 2:287-297.

Corvalan V, Cole R, deVellis J, Hagiwara S (1990) Neuronal modulation of calcium channel activity in cultured rat astrocytes. Proc Natl Acad Sci USA 87:4345-4348.

Dermietzel R, Hwang TK, Buettner R, Hofer A, Dotzler E, Kremer M, Deutzmann R, Thinnes FP, Fishman GI, Spray DC, Siemen D (1994) Cloning and in situ localization of a brain-derived porin that constitutes a large-conductance anion channel in astrocytic plasma membranes. Proc Natl Acad Sci USA 91:199-503.

Drenckhahn D, Schluter K, Allen DP, Bennett V (1985) Co-localization of band 3 with ankyrin and spectrin at the basal membrane of intercalated cells in the rat kidney. Science 230:1287-1289.

Faulstich H, Zobeley S, Rinnerthaler G, Small JV (1988) Fluorescent phallotoxins as probes for filamentous actin. J Muscle Res Cell Motil 9:370-383.

Ferroni S, Marchini C, Schubert P, Rapisarda C (1995) Two distinct inwardly rectifying conductances are expressed in long term dibutyryl-cyclicAMP treated rat cultured cortical astrocytes. FEBS Lett 367:319-325.

Froehner S (1991) The submembrane machinery for nicotinic acetylcholine receptor clustering. J Cell Biol 114:1-7.

Gardner-Medwin AR (1980) Membrane transport and solute migration affecting the cell microenvironment. Neurosci Res Program Bull 18:208-226.

Giulian D, Baker TJ (1986) Characterization of ameboid microglia isolated from developing mammalian brain. J Neurosci 6:2163-2178.

Goldman DE (1943) Potential, impedance, and rectification in membranes. J Gen Plyysiol 27:37-60.

Goldman JE, Abramson B (1990) Cyclic AMP-induced shape changes of astrocytes are accompanied by rapid depolymerization of actin. Brain Res 528:189_.196.

Gray PTA, Ritchie JM (1986) A voltage-gated chloride conductance in rat cultured astrocytes. Proc R Soc Lond [Biol] 228:267-288.

Greenfield (1992) Neuropathology, 5th Ed (Adams JH, Duchen LW, eds). New York: Oxford UP.
Guharay F, Sachs F (1984) Stretch-activated single ion channel currents in tissue-cultured embryonic skeletal muscle. J Physiol (Lond) 352:685-701

Hallows KR, Packman CH, Knauf PA (1991) Acute cell volume changes in anisotonic media affect F-actin content of HL-60 cells. Am J Physiol (Lond) 261:C1154-C1161.

I Ials GD, Palade PT (1990) Different sites control voltage dependence and conductance of a sarcoball anion channel. Biophys J 57:1037-1047.

Hamill OP, Marty A, Neher E, Sakmann B, Sigworth F (1981) Improved patch-clamp techniques for high resolution current recordings from cells and cell free membrane patches. Pflügers Arch 391:85-100.

Hatten ME (1985) Neuronal regulation of astroglial morphology and proliferation in vitro. J Cell Biol 104:1353-1360.

Haussler U, Rivet-Bastide M, Fahlke Ch Muller D, Zachar E, Rudel R (1994) Role of cytoskeleton in the regulation of $\mathrm{Cl}^{-}$channels in human embryonic skeletal muscle cells. Pflügers Arch 428:323-330.

Hille B (1992) Ionic channels of excitable membranes. Sunderland, MA: Sinauer.

Holevinsky KO, Jow F, Nelson DJ (1994) Elevation in intracellular calcium activates both chloride and proton currents in human macrophages. J Membr Biol 140:13-30.

Hudspeth AJ (1989) How the ear's works work. Nature 341:397-401.

Jackson PS, Strange K (1995) Characterization of the voltage-dependent properties of a volume-sensitive anion conductance. J Gen Physiol 105:661-677

Jalonen T (1993) Single-channel characteristics of the large-conductance anion channel in rat cortical astrocytes in primary culture. Glia 9:227-237.

Johnson BD, Byerly L (1993) A cytoskeletal mechanism for Ca channcl metabolic dependence and inactivation by intracellular $\mathrm{Ca}$. Neuron 10:797-804.

Kabsch W, Vandekerckhove J (1992) Structure and function of actin Annu Rev Biophys Biomol Struct 21:49-76.

Kettenmann H, Backus KH, Schachner M (1987) Gamma-aminobutyricacid opens $\mathrm{Cl}$ channels in cultured astrocytes. Brain Res 404:1-9.

Kimelberg HK, Bowman CL, Biddlecome S, Bourke RS (1979) Cation transport and membrane potential properties of primary astroglial cultures from neonatal rat brains. Brain Res 177:533-550.

Kimelberg HK, Bowman CL, Hirata H (1986) Anion transport in astrocytes. Ann NY Acad Sci 481:334-353.

Kimelberg HK, Rose JW, Barron KD, Waniewski RA, Cragow EJ (1989) Astrocytic swelling in traumatic-hypoxic brain injury. Mol Chem Neuropathol 11:1-31.

Kim-Lee MH, Stokes BT, Yates AJ (1992) Reperfusion paradox: a novel mode of glial cell injury. Glia 5:56-64.

Kraig RP, Chesler M (1988) Dynamics of volatile butters in brain cells during spreading depression. In: Mechanisms of cerebral hypoxia and stroke (Somjen G, ed), pp 279-289. New York: Plenum.

Kraig RP, Dong L, Thisted R, Jaeger CB (1991) Spreading depression increases immunohistochemical staining of glial fibrillary acidic protein. J Neurosci 11:2187-2198.

Levison SW, McCarthy KD (1991) Astroglia in culture. In: Culturing nerve cells (Banker G, Goslin K, eds), pp 309-336. Cambridge: MIT.

Levitan I, Nlmonte C, Mollard P, Garber SS (1995) Modulation of a volume-regulated chloride current by F-actin. J Membr Biol $147: 282-294$.

Lim R, Turriff DE, Troy SS (1976) Response of glioblasts to a morphological transforming factor: cinematographic and chemical correlations. Brain Res 113:165-170.

MacVicar BA, Tse FW, Crichton A, Kettenmann H (1989) GABAactivated $\mathrm{Cl}$ channels in astrocytes of hippocampal slices. J Neurosci 9:3577-3583.

Mathewson AJ, Berry M (1985) Observations on the astrocyte response to a cerebral stab wound in adult rats. Brain Res 327:61-69.

McCarthy KD, DeVellis J (1980) Preparation of separate astroglial and oligodendroglial cultures from rat cerebral tissue. J Cell Biol 85:890-902.

Miledi R, Parker I (1984) Chloride current induced by injection of calcium into xenopus oocytes. J Physiol (Lond) 357:173-183.

Mills JW, Schwiebert EM, Stanton BA (1994) Evidence for the role of actin filaments in regulating cell swelling. J Exp Zool 268:111-120.

Mobley PL, Hedberg K, Bonin L, Chen B, Griffith OH (1994) Decreased phosphorylation of four $20 \mathrm{kDa}$ proteins precedes staurosporineinduced disruption of the actin/myosin cytoskeleton in rat astrocytes. Exp Cell Res 214:55-66. 
Mobley PL, Scott SL, Cruz EG (1986) Protein kinase C in astrocytes: a determinant of cell morphology. Brain Res 398:366-369.

Nakao M, Gadsby DC (1989) [Na] and [K] dependence of the $\mathrm{Na} / \mathrm{K}$ pump current-voltage relationship in guinea pig ventricular myocytes. J Gen Physiol 94:539-565.

Neher E (1988) The influence of intracellular calcium concentration on degranulation of dialysed mast cells from rat peritoneum. J Physiol (Lond) 395:193-214.

Nelson WJ, Veshnock PJ (1987) Ankyrin binding to (Na + K) ATPase and implications for the organization of membrane domains in polarized cells. Nature 328:533-536.

Newman EA (1984) Regional specialization of retinal glial cell membrane. Nature 309:155-157.

Nowak L, Ascher P, Berwald-Netter Y (1987) Ion channels in mouse astrocytes in culture. J Neurosci 7:101-109.

Orkand RK, Nicholls JG, Kuffler SW (1966) Effect of nerve impulses on the membrane potential of glial cells in the central nervous system of amphibia. J Neurophysiol 29:788-806.

Pasantes-Morales H, Murray RA, Lilja L, Moran J (1994) Regulatory volume decrease in cultured astrocytes I. Potassium- and chlorideactivated permeability. Am J Physiol 266:C165-C171.

Petito CK, Morgello S, Felix JC, Lesser MI (1990) The two patterns of reactive astrocytosis in postischemic brain. J Cereb Blood Flow Metab 10:850-859.

Pollard 'I'D, Cooper JA (1986) Actin and actin-binding proteins: a critical evaluation of mechanisms and functions. Annu Rev Biochem 55:987-1035.
Pusch M, Neher E (1988) Rates of diffusional exchange between small cells and a measuring patch pipette. Pflügers Arch 411:204-211.

Ransom B, Kettenmann H (eds) (1995) Neuroglial cells. New York: Oxford UP.

Rosenmund C, Westbrook GL (1993) Calcium-induced actin depolymerization reduces NMDA channel activity. Neuron 10:805-814.

Sampath S, Pollard TD (1991) Effects of cytochalasin, phalloidin, and $\mathrm{pH}$ on the elongation of actin filaments. Biochemistry 30:1973-1980.

Schumann MA, Rafflin TA (1994) Activation of a voltage-dependent chloride current in human neutrophils by phorbol 12-myristate 13acetate and formyl-methionyl-leucyl-phenylalanine. The role of protein kinase C. J Biol Chem 269:2389-2398.

Schwiebert EM, Mills JW, Stanton BA (1994) Actin-based cytoskeleton regulates a $\mathrm{Cl}$ channel and cell volume in a renal cortical collecting duct cell line. J Biol Chem 269:7081-7089.

Sonnhof I (1987) Single voltage-dependent $\mathrm{K}$ and $\mathrm{Cl}$ channels in cultured rat astrocytes. Can J Physiol Pharmacol 65:1043-1050.

Srinivasan Y, Elmer L, Davis J, Bennett V, Angelides K (1988) Ankyrin and spectrin associate with voltage-dependent sodium channcls in brain. Nature 333:177-180.

Suzuki M, Miyazaki K, Ikeda M, Kawaguchi Y, Sakai O (1993) F-actin network may regulate a $\mathrm{Cl}$ channel in renal proximal tubule cells. J Membr Biol 134:31-39.

Uemura S, Young H, Matsuoka S, Nakanishi T, Jarmakani JM (1985) Calcium paradox in the neonatal heart. Can J Cardiol 1:114-120.

Walz W, Mukerji S (1988) $\mathrm{KCl}$ movements during potassium-induced cytotoxic swelling of cultured astrocytes. Exp Neurol 99:17-29. 